\title{
Contrasting Depositional Environment of Iron Formation at Endengue Area, NW Congo Craton, Southern Cameroon: New Insights from Trace and Rare Earth Elements Geochemistry
}

\section{Robinson Tchatchueng ${ }^{1}$, Timoléon Ngnotué ${ }^{1}$, Evine Laure Tanko Njiosseu ${ }^{1}$, Sylvestre Ganno ${ }^{2 *}$, Hervé Wabo ${ }^{3}$, Jean Paul Nzenti ${ }^{2}$}

${ }^{1}$ Department of Earth Sciences, University of Dschang, Dschang, Cameroon

${ }^{2}$ Department of Earth Sciences, University of Yaoundé, Yaoundé, Cameroon

${ }^{3}$ Department of Geology University of Johannesburg, Auckland Park, South Africa

Email: *sganno2000@yahoo.fr

How to cite this paper: Tchatchueng, R., Ngnotué, T., Njiosseu, E.L.T., Ganno, S., Wabo, H. and Nzenti, J.P. (2021) Contrasting Depositional Environment of Iron Formation at Endengue Area, NW Congo Craton, Southern Cameroon: New Insights from Trace and Rare Earth Elements Geochemistry. International Journal of Geosciences, 12, 280-306.

https://doi.org/10.4236/ijg.2021.123016

Received: February 3, 2021

Accepted: March 22, 2021

Published: March 25, 2021

Copyright $\odot 2021$ by author(s) and Scientific Research Publishing Inc. This work is licensed under the Creative Commons Attribution International License (CC BY 4.0).

http://creativecommons.org/licenses/by/4.0/

\section{(c) (i) Open Access}

\begin{abstract}
The Endengue Banded Iron Formation (BIF) is located in the northwestern edge of the Congo craton in Cameroon. Here, we report geochemical data of trace and rare earth elements (REE) of the Endengue BIF samples from the Archean Ntem complex and investigate their environmental setting. Two types of BIF occur at Endengue area, both containing minimal contamination from terrestrial material. Total REE ( $\Sigma$ REE) contents in the Type 1 BIF are extremely low, ranging from 0.34 to $1.83 \mathrm{ppm}$, similarly to pure chemical sediments while Type 2 BIF displays $\Sigma$ REE contents ranging from 2.98 to 24.26 ppm. The PAAS-normalized REE + Y patterns of the two BIF types display LREE enrichment relative to HREE and weak positive Eu anomaly, most likely suggesting that the source of iron and siliceous of the Endengue BIFs is mainly from the contribution of low-temperature hydrothermal alteration of the crust. Type 1 BIF shows very low $\mathrm{Nd}$ content $(<1 \mathrm{ppm})$ with positive correlation between $\mathrm{Nd}$ and $\mathrm{Ce} / \mathrm{Ce}^{\star}$ and positive $\mathrm{Ce}$ anomalies which suggests suboxic or anoxic seawater similar to the depositional environment of Elom BIF in Archean Ntem complex. In contrast, Type 2 BIF displays low to moderate $\mathrm{Nd}$ contents ( 1 and $100 \mathrm{ppm}$ with the exception of sample LBR65) with negative correlation between $\mathrm{Nd}$ and $\mathrm{Ce} / \mathrm{Ce}^{\star}$ and negative $\mathrm{Ce}$ anomalies. These features indicate precipatation of Type 2 BIF from oxic iron-rich solution that changed to oxidized surface by rapid precipitation of the hydrothermal Fe. The Endengue BIFs were deposited in the continental margin ocean in presence of low-temperature hydrothermal fluids mixed with seawater, similar to Paleoproterozoic Kpwa-Atog Boga BIFs within the Nyong
\end{abstract}


group and other Paleoproterozoic Superior-type BIFs worldwide.

\section{Keywords}

Endengue BIFs, Suboxic or Anoxic, Oxic, Depositional Environment, Ntem Complex

\section{Introduction}

The banded iron formations (BIFs) are chemical precipitated sediments, typically thin bedded or laminated, consisting of iron-rich content of sedimentary origin and layers of chert [1] [2] form from ancient seawater or into secular trends in the atmosphere-hydrosphere-lithosphere system. Such formations occur on all continents, are generally older than $1.7 \mathrm{Ga}$ and are highly metamorphosed. BIFs are largely constrained to the Precambrian marine sedimentary environment. The trace elements and Rare earth elements (REE) patterns are commonly used to characterize minerals and rocks, and to clarify their evolution and origin [3]. Trace and Rare earth elements (REE) of BIFs significantly contribute in understanding their genesis, and their environment setting [4] [5]. Since BIFs are considered as chemical/biochemical sediments that precipitated from ocean water [2] [6] [7], the trace element, including the REE distribution of BIFs, has been widely used as chemical substitute to determine the origin and depositional setting into the ocean water chemistry through time [7] [8] [9] [10]. Trace elements can be used to determine the origin of impurity like clastic or crustal materials [4] [11]. On the other hand, the relative concentration of REE has been used as proxies to tracers for oceanic water masses [12] [13], oceanic input sources and seawater chemistry environment deposit [14].

In Cameroon, the Archean Ntem Complex is one of favorable environment setting of BIFs deposit. Previous studies revealed that the BIFs of the Archean Ntem complex were deposited within various environments. For instance, [15] used REE elements to suggest that the Njweng BIFs have the same characteristic similar to that of modern seawater environmental setting. In contrast, the BIFs within the Elom area studied by [16] indicate that they were formed inside a redox stratified ocean. However, the Bikoula BIF is considered to have been deposited in a basin that was anoxic or suboxic [17]. In Nkout area, [18] suggested that the BIFs have clastic contamination in a depositional environment closer to the continent. The Endengue BIF deposits associated with metamorphic rocks have been discovered in the Archean Ntem Complex (Figure 1(b)). However, the environment setting of the Endengue BIFs remains unknown.

In this study, we report trace and REE elements geochemistry of Endengue BIF deposits in the northern part of Congo Craton in order to investigate the depositional environment and the conditions that prevailed during the precipitation of BIFs. Furthermore, our data are compared to modern day seawater 
$\mathrm{REE}+\mathrm{Y}$ and chemical sediments that best represent the REE $+\mathrm{Y}$ signature of seawater at the time of precipitation.

\section{Geological Setting}

The Ntem complex represents the northwestern edge of the Congo craton in Central Africa and comprises the Archaean Ntem and Ayina groups and Archaean to Paleoproterozoic Nyong group (Figure 1(a)). The Nyong group includes a metasedimentary and metavolcanic rocks, as well as syn- to late-tectonic granitoids and syenites [20] [21] [22]. The Ayina group is dominated by Mbalam volcano-sedimentary series, granitoids and as well as supracrustal rocks [15] [19] [23]. The Ntem group is mainly composed of two main series namely, intrusive series and banded series, and various Supracrustal rocks [19] [21] [24] [25]. The intrusive series is characterized by various Tonalite-Trondhjemite-Granodiorite (TTG) suite dated at $2.88-2.830 \mathrm{Ga}$ [20] [21] [26] [27] [28] [29] [30] and charnockitic suite (charnockite, charnockitic gneiss, charno-enderbite, enderbite) emplaced at ca. $3.266-2.879 \mathrm{Ga}$ [21] [28] [30] [31]. The banded series is essentially dominated by strongly deformed granitic gneisses associated with charnockitic enclaves found within the gneisses. The supracrustal rocks include greenstone belts, BIFs, metabasites (garnet-bearing amphibolites, pyroxenites) and metavolcanic rocks dated at 3.147 and $2.883 \mathrm{Ga}$ [16] [17] [18] [32] [33] [34]. The K-rich granitoids and dolerite dykes intruded the TTG and greenstone belts [16] [20] [24] [35] [36]. The K-rich granitoids are derived from partial melting of charnockitic rocks [35] [36].

Recent reviews of the geochronological data of the Ntem group [37] suggest that the charnockites and TTG suites of Sangmelima formed at $3.155-2.850 \mathrm{Ga}$ and the gabbro intrusion was dated at $2.866 \mathrm{Ga}$.

The Archean Ntem Complex is marked by two major tectonic events namely $D_{1}$ and $D_{2}$. The $D_{1}$ phase is dominated by $S_{1}$ foliation which affected both the intrusive and banded series. The intrusive series is marked by NW-SE to NNE-SSW and SW-trending $\left(\mathrm{S}_{1}\right)$ vertical foliation, and subhorizontal lineation and the banded series by ENE-WSW to E-W striking $S_{1}$ foliation and E-W trending $L_{1}$ stretching lineation. The $\mathrm{D}_{2}$ phase is characterized by NE-SW to WNW-ESEtrending sinistral or dextral strike-slip fault and has been assigned to Paleoproterozoic (Eburnean orogeny) event [19] [28] [29] [38] [39].

The metamorphic rocks are generally of HT-LP amphibolite to granulite facies $\left(600^{\circ} \mathrm{C}-737^{\circ} \mathrm{C}, 5.3\right.$ to $\left.6.5 \pm 0.5 \mathrm{kbar}\right)$ in meta-igneous and sedimentary rocks [29]. Numerous K-rich granitoid dykes were emplaced during the late Archean tectonothermal event (ca. 2.6 Ga) [24].

New geochronological data have revealed that the migmatisation of TTG-gneiss was coeval with the regional high-grade metamorphism event at $2.843 \mathrm{Ga}$; the potassic granites were probably crystallized at $\sim 2.758 \mathrm{Ga}$ and the garnet-whole rock age of $2.744 \mathrm{Ga}$ could date the second anatexis event coeval with $\mathrm{D}_{2}$ deformation [37]. 

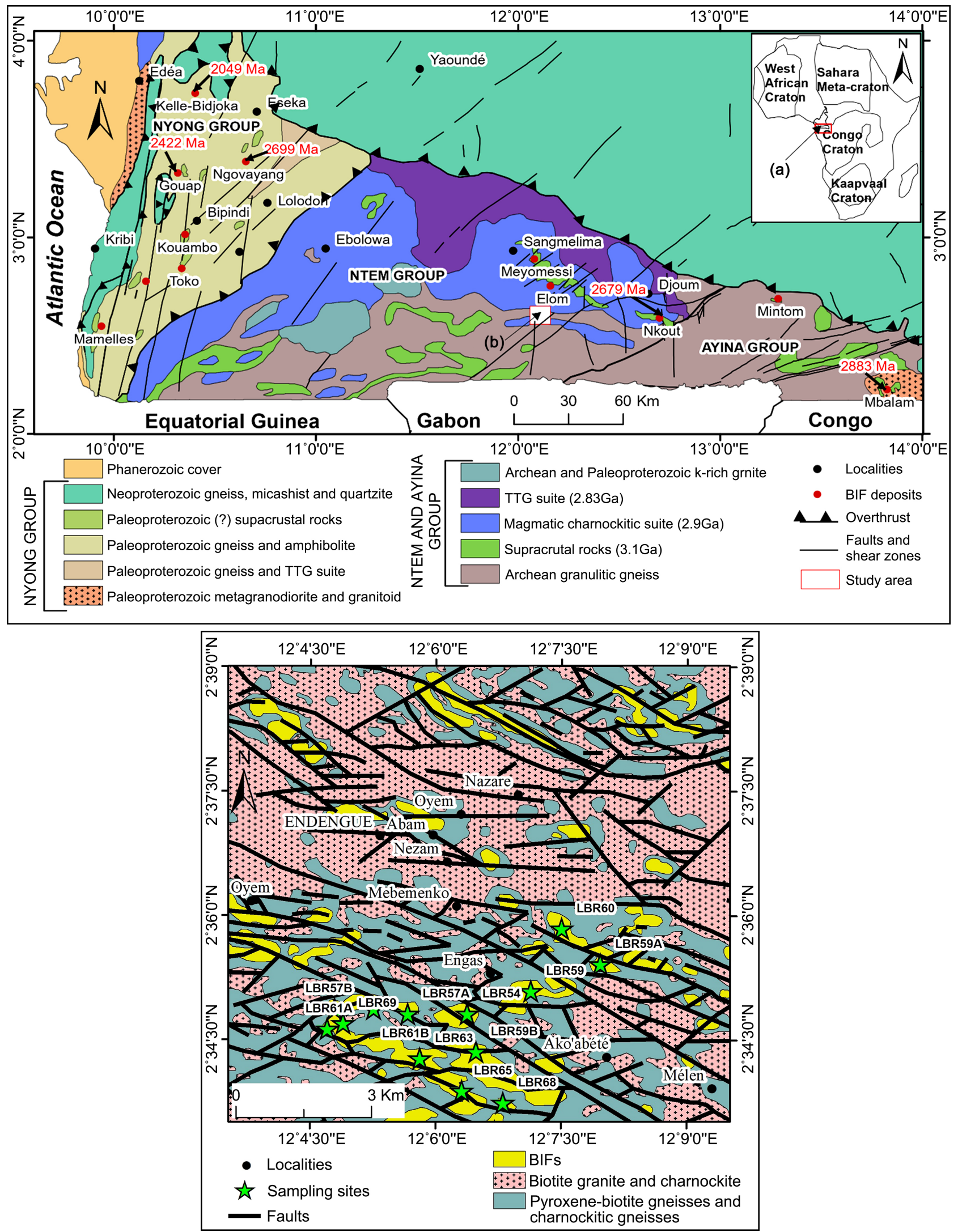

Figure 1. Geological map of SW Cameroon (modified after [19]) showing the Endengue area with some zone of BIFs hosted the Ntem Complex (a). Geological sketch map of the Endengue area showing samples location (b). 
The Endengue iron mineralization is located within the Archean Ntem Complex (Figure 1(b)). The main rock types of the Endengue area are metamorphosed banded iron formations (BIFs), pyroxene-biotite gneisses, and charnockitic gneisses, charnockites and biotite granites. Structurally, the Endengue area is characterized by three main tectonic events namely $D_{1}$ and $D_{2}$. The $D_{1}$ phase is marked by $S_{1}$ foliation with strikes E-W with a near vertical dips (average $49^{\circ}$ ). The $\mathrm{D}_{2}$ phase is characterized by $\mathrm{N} 103^{\circ} \mathrm{E}$ trending sinistral strike $\mathrm{C}_{2}$ shear zone and $\beta_{2}$ boudins. The $D_{3}$ is a brittle phase marked by the fractures, and veins.

\section{Sampling and Analytical Methods}

Samples were collected from outcrops of the iron ore prospect. Twelve fresh representative samples of BIFs were carefully selected on the basis of their mineral chemistry and whole rock geochemistry. Locations of sampling sites are shown in Figure 1(b). Whole-rock analyses were performed by Inductively Coupled Plasma Mass Spectrometry (ICP-MS) for trace elements and REE at Australian Laboratory Services (ALS) in Vancouver (Canada). The samples were pulverized to obtain a homogeneous sample out of which 50 - $60 \mathrm{~g}$, was obtained for the analyses. $0.2 \mathrm{~g}$ of rock powder was fused with $1.5 \mathrm{~g} \mathrm{LiBO} 2$ and then dissolved in $100 \mathrm{~mm}^{3} 5 \% \mathrm{HNO}$. Analytical uncertainties vary from $0.1 \%$ to $0.5 \%$ for trace elements and 0.01 to $0.5 \mathrm{ppm}$ for rare earth elements. Various standards were used and data quality assurance was verified by running these standards between samples as unknowns. Analysis precision for rare earth elements is estimated at $5 \%$ for concentrations $>10 \mathrm{ppm}$ and $10 \%$ when lower.

\section{Results}

\subsection{Trace Elements}

\subsubsection{Type 1 BIF}

The trace elements chemical compositions are reported in Table 1. No significant enrichment of trace element is observed in the type 1 BIF. The Upper Continental Crust composition [40]; Figure 2(a) shows lower content of transition trace metals, high field strength elements (HFSE), and REE. The type 1 BIF displays lower transition metals values such as $\mathrm{Cr}(3.53-4.05 \mathrm{ppm}), \mathrm{Zn}(0.3-2.47$ ppm), $\mathrm{Pb}(0.064-0.295 \mathrm{ppm}), \mathrm{Ni}(<0.05-0.19 \mathrm{ppm}), \mathrm{Cu}(<0.05-0.28 \mathrm{ppm})$ and $\mathrm{V}(0.82-0.89 \mathrm{ppm})$. The HFSE show extreme low contents of $\mathrm{Zr} \leq 0.004 \mathrm{ppm}, \mathrm{U}$ $(0.015-0.050 \mathrm{ppm})$ and Th $(0.002-0.053 \mathrm{ppm})$ compared to the LILE with low concentration of $\mathrm{Rb}(0.28-0.95 \mathrm{ppm})$; $\mathrm{Sr}(0.913-8.4 \mathrm{ppm})$; $\mathrm{Cs}(0.006-0.02$ $\mathrm{ppm})$. The extremely low concentrations of $\mathrm{Cr}, \mathrm{Zr}$ and $\mathrm{V}$ indicate a minimal supply of terrigenous material in primary chemogenic sediments [41].

\subsubsection{Type $2 \mathrm{BIF}$}

Regarding the composition of trace element, no important enrichment was noticed. When compared to the average upper continental crust [40], the studied BIFs are depleted in high field strength elements (Ta, Th, $\mathrm{U}, \mathrm{Zr}$ ), transition met- 
als $(\mathrm{Cr}, \mathrm{Zn}, \mathrm{Pb}, \mathrm{Ni}, \mathrm{Cu}, \mathrm{V}$ ) and large ion lithophile elements (Sr, Rb, Cs) (Figure 2(b)). The type $2 \mathrm{BIF}$ is depleted in transition metals such as $\mathrm{Cr}(3.85-4.1 \mathrm{ppm})$, $\mathrm{Zn}(0.4-2.95 \mathrm{ppm}), \mathrm{Pb}(0.098-0.339 \mathrm{ppm}), \mathrm{Ni}(<0.05-0.66 \mathrm{ppm}), \mathrm{Cu}(0.06-$ $0.24 \mathrm{ppm})$ and $\mathrm{V}(0.88-0.9 \mathrm{ppm})$. The high field strength elements (HFSE) such as $\mathrm{Th}(0.008-0.99 \mathrm{ppm}), \mathrm{U}(0.01-0.05)$ and $\mathrm{Zr}(<0.001-0.002 \mathrm{ppm})$ show lower contents compared to large ion lithophile elements (LILE) $(\mathrm{Rb}=0.28-0.95$; $\mathrm{Sr}=0.913-8.4$; $\mathrm{Cs}=0.006-0.02 \mathrm{ppm}$ ). The type $2 \mathrm{BIF}$ differs from type 1 ones by having higher contents of trace elements (Table 1; Figure 2).

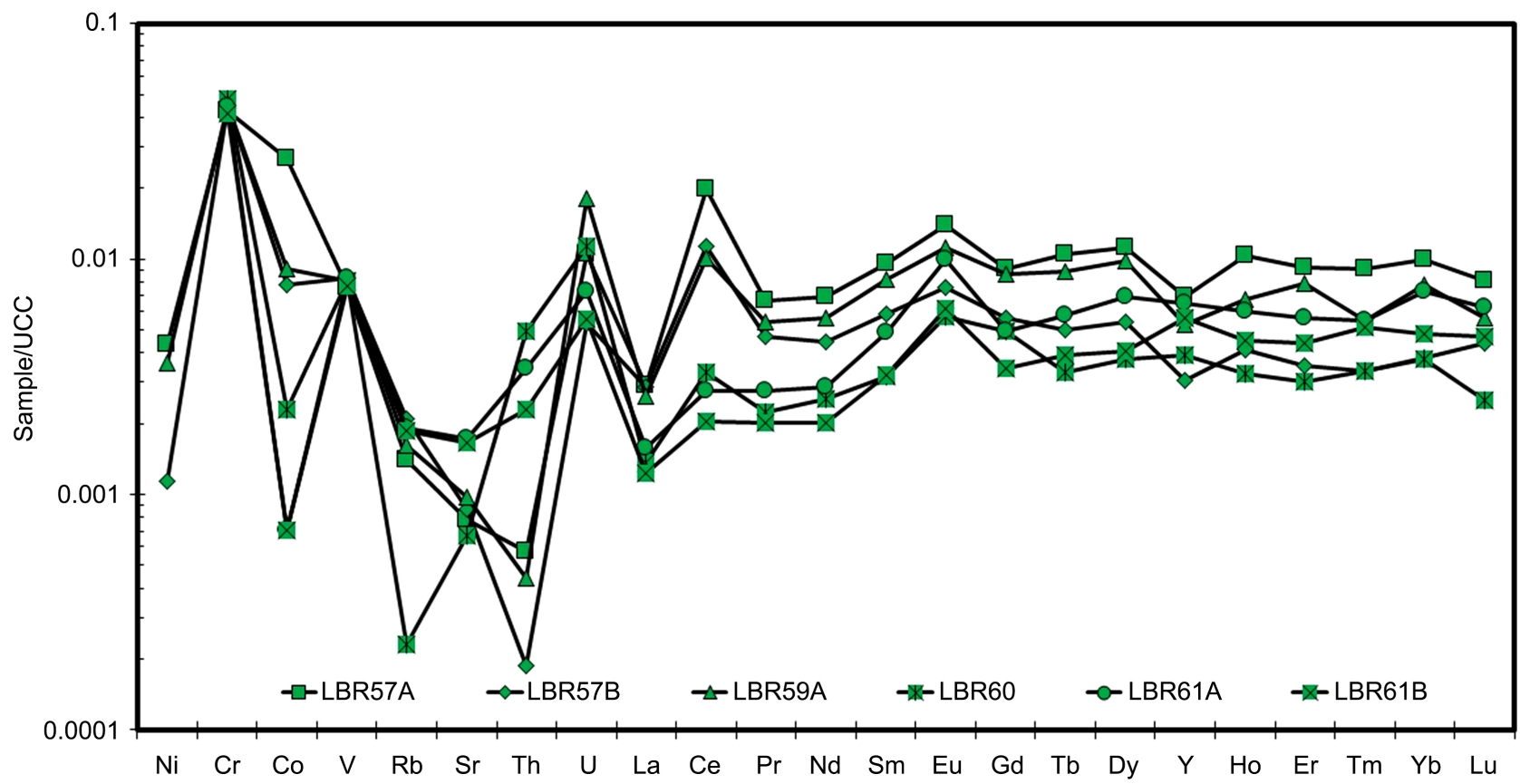

(a)

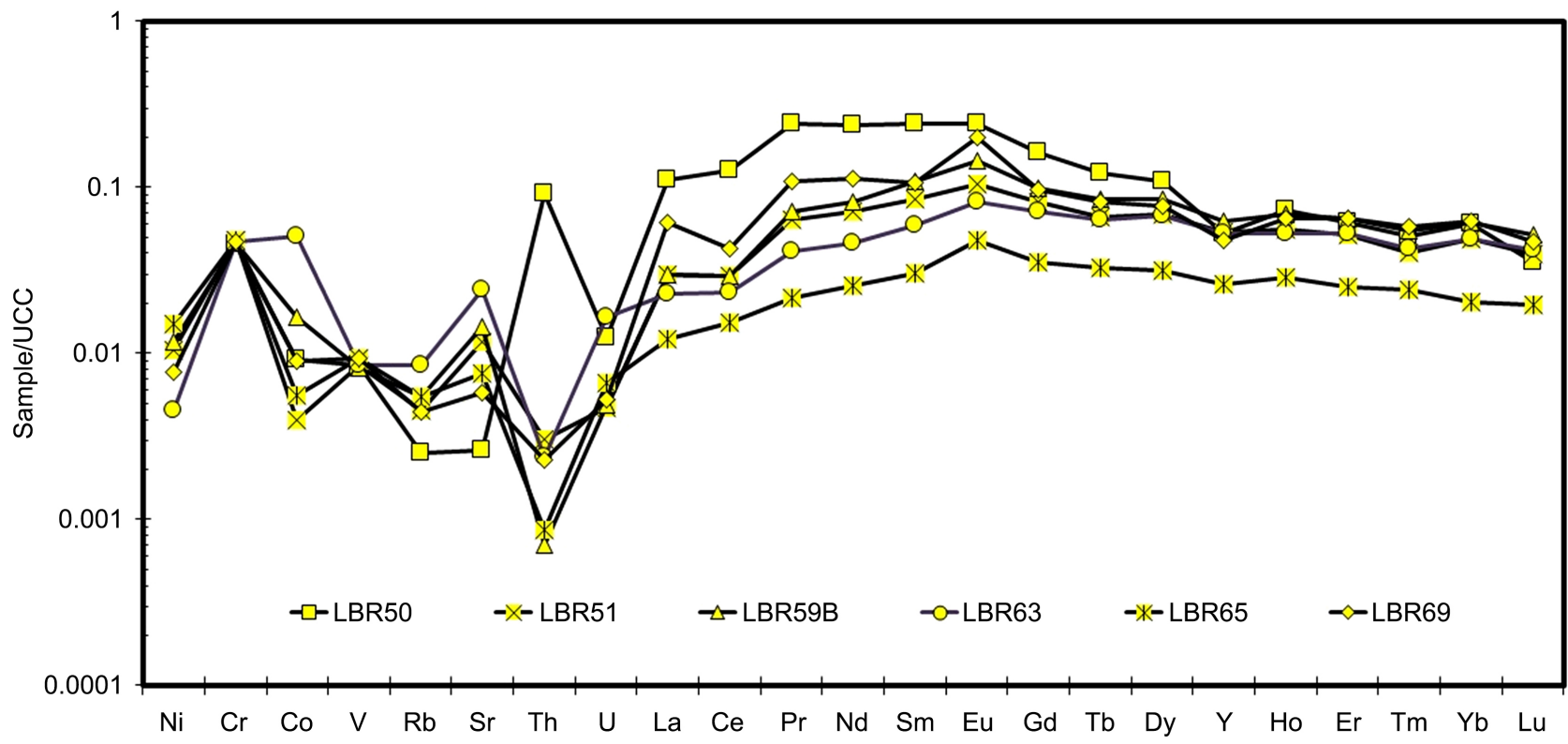

(b)

Figure 2. Upper Continental Crust (UCC)-normalized spider diagrams, from [41]. 
Table 1. Trace and REE compositions (ppm) of the Endengue BIFs.

\begin{tabular}{|c|c|c|c|c|c|c|c|c|c|c|c|c|c|c|}
\hline \multirow{2}{*}{ Samples } & \multicolumn{7}{|c|}{ Type 1 BIF } & \multicolumn{7}{|c|}{ Type 2 BIF } \\
\hline & LBR57A & LBR57B & LBR59A & LBR60 & LBR61A & LBR61B & Mean & LBR50 & LBR51 & LBR59B & LBR63 & LBR65 & LBR69 & Mean \\
\hline \multicolumn{15}{|l|}{ ppm } \\
\hline $\mathrm{V}$ & 0.81 & 0.89 & 0.87 & 0.86 & 0.89 & 0.82 & 0.86 & 0.91 & 0.9 & 0.88 & 0.91 & 0.99 & 0.99 & 0.92 \\
\hline $\mathrm{Cr}$ & 3.62 & 3.82 & 3.82 & 4.05 & 3.77 & 3.53 & 3.77 & 3.85 & 4.04 & 3.93 & 4 & 4.1 & 4.01 & 3.99 \\
\hline Co & 0.455 & 0.132 & 0.155 & 0.039 & 0.012 & 0.012 & 0.13 & 0.157 & 0.067 & 0.279 & 0.86 & 0.094 & 0.154 & 0.29 \\
\hline $\mathrm{Ni}$ & 0.19 & 0.05 & 0.16 & $<0.05$ & $<0.05$ & $<0.05$ & 0.13 & $<0.05$ & 0.46 & 0.52 & 0.2 & 0.66 & 0.34 & 0.46 \\
\hline $\mathrm{Cu}$ & 0.13 & 0.11 & 0.28 & $<0.05$ & 0.1 & 0.06 & 0.14 & 0.06 & 0.08 & 0.31 & 0.24 & 0.24 & 0.21 & 0.19 \\
\hline W & 0.01 & 0.005 & 0.005 & 0.006 & 0.003 & 0.004 & 0.006 & 0.005 & 0.005 & 0.004 & 0.004 & 0.031 & 0.026 & 0.01 \\
\hline $\mathrm{Zn}$ & 0.65 & 0.5 & 0.41 & 0.3 & 2.47 & 0.34 & 0.78 & 1.16 & 0.46 & 0.4 & 2.95 & 0.57 & 1.07 & 1.11 \\
\hline $\mathrm{Rb}$ & 0.157 & 0.235 & 0.182 & 0.026 & 0.215 & 0.208 & 0.17 & 0.283 & 0.511 & 0.618 & 0.952 & 0.618 & 0.498 & 0.60 \\
\hline $\mathrm{Sr}$ & 0.274 & 0.302 & 0.343 & 0.234 & 0.606 & 0.58 & 0.39 & 0.913 & 4.1 & 5.06 & 8.4 & 2.67 & 2.02 & 4.23 \\
\hline Mo & 0.001 & $<0.001$ & 0.002 & $<0.001$ & 0.001 & 0.001 & 0.001 & 0.002 & 0.002 & 0.002 & 0.005 & 0.002 & 0.002 & 0.003 \\
\hline Cs & 0.0031 & 0.006 & 0.0014 & 0.0008 & 0.0237 & 0.0175 & 0.009 & 0.0059 & 0.0183 & 0.0125 & 0.0108 & 0.0114 & 0.0063 & 0.012 \\
\hline $\mathrm{Ti}$ & 0.15 & 0.14 & 0.15 & 0.07 & 0.07 & 0.05 & 0.11 & 0.08 & 0.12 & 0.27 & 0.16 & 0.3 & 0.13 & 0.18 \\
\hline $\mathrm{Tl}$ & 0.012 & 0.002 & 0.006 & 0.002 & 0.005 & 0.004 & 0.005 & 0.005 & 0.003 & 0.006 & 0.011 & 0.003 & 0.002 & 0.005 \\
\hline $\mathrm{Zr}$ & 0.003 & 0.002 & 0.001 & 0.004 & 0.002 & 0.002 & 0.002 & 0.001 & $<0.001$ & 0.002 & 0.001 & $<0.001$ & 0.002 & 0.001 \\
\hline $\mathrm{U}$ & 0.0292 & 0.015 & 0.0506 & 0.0318 & 0.0205 & 0.0156 & 0.027 & 0.0348 & 0.0131 & 0.0138 & 0.0465 & 0.0184 & 0.0147 & 0.025 \\
\hline $\mathrm{Pb}$ & 0.25 & 0.156 & 0.13 & 0.295 & 0.098 & 0.064 & 0.17 & 0.207 & 0.098 & 0.265 & 0.145 & 0.339 & 0.291 & 0.21 \\
\hline Th & 0.0061 & 0.002 & 0.0047 & 0.0529 & 0.0367 & 0.0245 & 0.021 & 0.985 & 0.0325 & 0.0075 & 0.0256 & 0.0093 & 0.0246 & 0.21 \\
\hline $\mathrm{La}$ & 0.146 & 0.143 & 0.13 & 0.068 & 0.079 & 0.062 & 0.11 & 5.56 & 1.48 & 1.5 & 1.13 & 0.608 & 3.05 & 2.06 \\
\hline $\mathrm{Ce}$ & 1.27 & 0.721 & 0.646 & 0.21 & 0.1755 & 0.1315 & 0.53 & 8.06 & 1.86 & 1.88 & 1.485 & 0.972 & 2.74 & 2.85 \\
\hline $\operatorname{Pr}$ & 0.047 & 0.033 & 0.038 & 0.016 & 0.020 & 0.014 & 0.03 & 1.71 & 0.448 & 0.503 & 0.293 & 0.153 & 0.767 & 0.62 \\
\hline $\mathrm{Nd}$ & 0.179 & 0.116 & 0.147 & 0.066 & 0.074 & 0.052 & 0.11 & 6.2 & 1.845 & 2.14 & 1.19 & 0.661 & 2.95 & 2.41 \\
\hline $\mathrm{Sm}$ & 0.0429 & 0.0262 & 0.037 & 0.0142 & 0.0218 & 0.0145 & 0.03 & 1.09 & 0.38 & 0.49 & 0.264 & 0.136 & 0.483 & 0.47 \\
\hline $\mathrm{Eu}$ & 0.012 & 0.007 & 0.0100 & 0.005 & 0.009 & 0.005 & 0.008 & 0.211 & 0.092 & 0.127 & 0.071 & 0.043 & 0.177 & 0.11 \\
\hline $\mathrm{Gd}$ & 0.035 & 0.021 & 0.033 & 0.019 & 0.019 & 0.013 & 0.02 & 0.617 & 0.312 & 0.375 & 0.273 & 0.135 & 0.367 & 0.34 \\
\hline $\mathrm{Tb}$ & 0.007 & 0.003 & 0.006 & 0.002 & 0.004 & 0.003 & 0.004 & 0.078 & 0.042 & 0.055 & 0.041 & 0.021 & 0.053 & 0.047 \\
\hline Dy & 0.039 & 0.019 & 0.035 & 0.013 & 0.024 & 0.014 & 0.02 & 0.379 & 0.24 & 0.297 & 0.235 & 0.11 & 0.271 & 0.25 \\
\hline $\mathrm{Y}$ & 0.153 & 0.067 & 0.116 & 0.086 & 0.142 & 0.124 & 0.11 & 1.16 & 1.175 & 1.375 & 1.15 & 0.571 & 1.055 & 1.09 \\
\hline Ho & 0.008 & 0.003 & 0.005 & 0.003 & 0.0048 & 0.004 & 0.005 & 0.059 & 0.045 & 0.055 & 0.042 & 0.023 & 0.052 & 0.045 \\
\hline
\end{tabular}




\section{Continued}

\begin{tabular}{|c|c|c|c|c|c|c|c|c|c|c|c|c|c|c|}
\hline Er & 0.021 & 0.008 & 0.018 & 0.007 & 0.013 & 0.010 & 0.01 & 0.14 & 0.118 & 0.15 & 0.121 & 0.058 & 0.148 & 0.12 \\
\hline $\mathrm{Tm}$ & 0.003 & 0.001 & 0.002 & 0.001 & 0.002 & 0.002 & 0.002 & 0.017 & 0.013 & 0.0179 & 0.0141 & 0.008 & 0.019 & 0.014 \\
\hline $\mathrm{Yb}$ & 0.022 & 0.008 & 0.017 & 0.008 & 0.016 & 0.011 & 0.01 & 0.132 & 0.107 & 0.136 & 0.108 & 0.045 & 0.138 & 0.11 \\
\hline $\mathrm{Lu}$ & 0.003 & 0.001 & 0.002 & 0.0008 & 0.002 & 0.0015 & 0.002 & 0.0113 & 0.0126 & 0.0166 & 0.0134 & 0.0063 & 0.015 & 0.012 \\
\hline LREE & 1.64 & 1.64 & 1.64 & 0.36 & 0.35 & 0.26 & 0.76 & 21.53 & 5.63 & 6.02 & 4.10 & 2.39 & 9.51 & 7.94 \\
\hline MREE & 0.14 & 0.08 & 0.13 & 0.06 & 0.08 & 0.05 & 0.09 & 2.43 & 1.11 & 1.40 & 0.9 & 0.47 & 1.40 & 1.27 \\
\hline HREE & 0.05 & 0.02 & 0.04 & 0.02 & 0.03 & 0.02 & 0.03 & 0.30 & 0.25 & 0.32 & 0.26 & 0.12 & 0.32 & 0.25 \\
\hline LREE/HREE & 33.57 & 53.27 & 24.65 & 21.06 & 10.65 & 10.87 & 25.68 & 71.74 & 22.49 & 18.79 & 16.01 & 20.44 & 29.71 & 29.89 \\
\hline$\Sigma \mathrm{REE}+\mathrm{Y}$ & 1.99 & 1.18 & 1.24 & 0.52 & 0.59 & 0.45 & 0.99 & 25.42 & 8.17 & 9.12 & 6.43 & 3.55 & 12.28 & 10.83 \\
\hline $\mathrm{Eu} / \mathrm{Sm}$ & 0.29 & 0.26 & 0.26 & 0.35 & 0.40 & 0.37 & 0.31 & 0.19 & 0.24 & 0.26 & 0.27 & 0.31 & 0.37 & 0.23 \\
\hline $\mathrm{Co} / \mathrm{Zn}$ & 0.7 & 0.264 & 0.378 & 0.13 & 0.005 & 0.035 & 0.17 & 0.135 & 0.146 & 0.698 & 0.292 & 0.165 & 0.145 & 0.26 \\
\hline $\mathrm{Y} / \mathrm{Ho}$ & 18.37 & 20.30 & 21.39 & 33.00 & 29.58 & 34.31 & 26.16 & 19.80 & 26.17 & 24.91 & 27.32 & 24.93 & 20.37 & 23.92 \\
\hline$(\mathrm{La} / \mathrm{Yb})_{\mathrm{CN}}$ & 4.743 & 12.168 & 5.421 & 5.903 & 31.561 & 26.076 & 14.31 & 30.214 & 9.968 & 7.911 & 7.54 & 9.735 & 15.853 & 13.54 \\
\hline$(\mathrm{La} / \mathrm{Sm})_{\mathrm{CN}}$ & 2.189 & 3.511 & 2.268 & 3.105 & 2.345 & 2.751 & 2.70 & 3.293 & 2.514 & 1.976 & 2.763 & 2.886 & 4.077 & 2.92 \\
\hline$\left(\mathrm{Gd} / \mathrm{Gd}^{*}\right)_{\mathrm{SN}}$ & 0.89 & 1.06 & 0.99 & 1.51 & 0.90 & 0.92 & 1.04 & 1.00 & 1.13 & 1.05 & 1.15 & 1.11 & 1.06 & 1.08 \\
\hline$(\mathrm{Tb} / \mathrm{Yb})_{\mathrm{CN}}$ & 1.384 & 1.732 & 1.506 & 1.150 & 9.343 & 6.684 & 3.63 & 2.676 & 1.797 & 1.828 & 1.712 & 2.121 & 1.736 & 1.98 \\
\hline$\left(\mathrm{Eu} / \mathrm{Eu}^{*}\right)_{\mathrm{CN}}$ & 0.976 & 0.867 & 0.860 & 0.938 & 1.314 & 1.202 & 1.03 & 0.787 & 0.817 & 0.902 & 0.812 & 0.959 & 1.285 & 0.93 \\
\hline$(\mathrm{La} / \mathrm{Yb})_{\mathrm{SN}}$ & 0.49 & 1.25 & 0.56 & 0.61 & 0.37 & 9.24 & 2.09 & 3.11 & 1.03 & 0.81 & 1.00 & 1.63 & 0.76 & 1.39 \\
\hline$(\mathrm{Tb} / \mathrm{Yb})_{\mathrm{SN}}$ & 1.11 & 1.39 & 1.21 & 0.92 & 7.49 & 5.34 & 2.91 & 2.14 & 1.44 & 1.47 & 1.37 & 1.70 & 1.39 & 1.59 \\
\hline$\left(\mathrm{Eu} / \mathrm{Eu}^{*}\right)_{\mathrm{SN}}$ & 1.50 & 1.34 & 1.32 & 1.41 & 2.02 & 1.85 & 1.57 & 1.19 & 1.26 & 1.39 & 1.24 & 1.47 & 1.98 & 1.42 \\
\hline$\left(\mathrm{Pr} / \mathrm{Pr}^{\star}\right)_{\mathrm{SN}}$ & 0.50 & 0.60 & 0.70 & 0.78 & 1.01 & 1.02 & 0.77 & 1.36 & 1.30 & 1.31 & 1.23 & 1.09 & 1.43 & 1.29 \\
\hline$\left(\mathrm{Ce} / \mathrm{Ce}^{\star}\right)_{\mathrm{SN}}$ & 3.48 & 2.42 & 2.09 & 1.47 & 1.03 & 1.02 & 1.92 & 0.60 & 0.52 & 0.49 & 0.59 & 0.73 & 0.41 & 0.56 \\
\hline$\left(\mathrm{La} / \mathrm{La}^{*}\right)_{\mathrm{SN}}$ & 0.69 & 0.84 & 0.78 & 1.21 & 0.92 & 0.89 & 0.89 & 0.67 & 0.89 & 0.88 & 1.01 & 1.23 & 0.92 & 0.93 \\
\hline$\left(\mathrm{Y} / \mathrm{Y}^{\star}\right)_{\mathrm{SN}}$ & 0.67 & 0.68 & 0.67 & 1.17 & 1.05 & 1.37 & 0.94 & 0.61 & 0.90 & 0.85 & 0.92 & 0.91 & 0.71 & 0.82 \\
\hline
\end{tabular}

Note: Chondrite (CI, subscript CN, [47]) and post-Archean Australian shale (PAAS, subscript SN, [48]). The REE-Y ratios are obtained as follow: (La/La $\left.{ }^{*}\right)_{S N}$

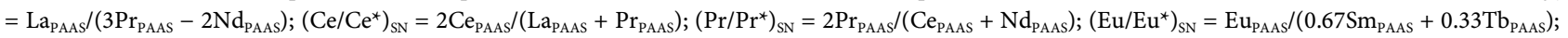
$\left(\mathrm{Y} / \mathrm{Y}^{*}\right)_{\mathrm{SN}}=2 \mathrm{Y}_{\mathrm{PAAS}} \mathrm{S}\left(\mathrm{DY}_{\mathrm{PAAS}}+\mathrm{Ho}_{\mathrm{PAAS}}\right)$.

The studied BIFs show very low concentration of $\mathrm{V}, \mathrm{Rb}$ and $\mathrm{Sr}$ compared to data reported from the terrigenous sediments by [42]. Th, $\mathrm{Nb}$ and $\mathrm{Zr}$ contents of our samples are also very low, indicating that the trace elements were most likely contaminated by terrigenous components. Nevertheless, when likened compared to upper continental crust, extremely low contents observed in incompatible elements ( $\mathrm{Ta}, \mathrm{Th}, \mathrm{U}$ and $\mathrm{Zr}$ ) show a loss to non-detrital origin for the silicates [43]. In addition, the two types of BIFs shown coherent patterns on a [40] normalized trace element plot, with pronounced negative $\mathrm{Ni}, \mathrm{Rb}$ and positive $\mathrm{Cr}$ 
anomalies (Figure 2).

\subsection{Rare Earth Elements}

Given its similar behavior to REE, yttrium (Y) is plotted along with these elements (between Dy and Ho) based on its ionic radius [44] [45]. The $\Sigma$ REE + Y from both types of BIFs are shown in Table 1. All the selected samples of the Endengue BIFs are characterized by low $\Sigma \mathrm{REE}+\mathrm{Y}$ values, which range from 0.45 to $25.42 \mathrm{ppm}$ (Table 1$)$. The rare earth elements and yttrium (REE + Y) geochemical data are normalized to Upper Continental Crust (UCC: [40], C1 chondrite [46]) and to Post Archean Australian Shale (PAAS: [47]).

\subsubsection{Type 1 BIF}

The type 1 BIF displays widely variable low contents of REE + Y (0.45 - 1.99 ppm, $0.99 \mathrm{ppm}$ on average). The light rare earth element (LREE) concentrations are higher than those of middle rare earth elements (MREE) and the heavy rare earth elements (HREE) (Table 1).

The chondrite-normalized REE diagram (Table 1; Figure 3(a)), of the type 1 BIF display, absent to positive Ce anomalies, LREE-enriched $\left((\mathrm{La} / \mathrm{Yb})_{\mathrm{CN}}=4.74-\right.$ $31.56)$ and HREE-depleted $\left((\mathrm{Tb} / \mathrm{Yb})_{\mathrm{CN}}=1.38-9.34\right)$. It is interesting to note that, the type $1 \mathrm{BIF}$, shows weak positive $\mathrm{Eu}$ anomalies with $\left(\mathrm{Eu} / \mathrm{Eu}^{*}\right)_{\mathrm{CN}}$ contents ranging from 0.86 and 1.31 (Table 1; Figure 3(a)). These observations are consistent with the suggestion of [8] [48] [49] [50] that the Eoarchean BIFs are characterized by largest $\mathrm{Eu}$ anomalies and the Mesoproterozoic BIFs with smallest $\mathrm{Eu}$ anomalies. The type $1 \mathrm{BIF}$ shows an average ratio $\left((\mathrm{Sm} / \mathrm{Yb})_{\mathrm{CN}}=2.16\right)$. The lack of positive Eu anomaly in chondrite-normalized patterns is therefore revealing of Paleoproterozoic age of the studied BIF.

When compared to the PAAS-normalized REE + Y diagram (Table 1, Figure $3(\mathrm{c})$ ), type 1 BIF exhibits low REE with average concentration of $0.99 \mathrm{ppm}$. This BIF type is generally depleted in LREE relative to HREE with $(\mathrm{Tb} / \mathrm{Yb})_{S N}$ ratios ranging from 0.92 - 7.49. This BIF however shows slightly positive La, Gd, Y anomalies with $\left(\mathrm{La} / \mathrm{La}^{*}\right)_{S \mathrm{~N}}=0.69-1.21,\left(\mathrm{Gd} / \mathrm{Gd}^{*}\right)_{S \mathrm{~N}}=0.89-1.51$ and $\left(\mathrm{Y} / \mathrm{Y}^{*}\right)_{S \mathrm{~N}}$ $=0.67-1.37$, positive $\mathrm{Ce}$ anomalies with $\left(\mathrm{Ce} / \mathrm{Ce}^{\star}\right)_{S \mathrm{~N}}=1.02-3.48$ and chondritic $\mathrm{Y} / \mathrm{Ho}$ ratios $(\mathrm{Y} / \mathrm{Ho}=18.37-34.31$, average: 26.16$)$. Furthermore, type $1 \mathrm{BIF}$ is characterized by very low $\mathrm{Nd}$ concentrations ranging between 0.06 and 0.18 (less than $1 \mathrm{ppm}$ ) with positive correlation between $\mathrm{Nd}$ concentration and $\mathrm{Ce} / \mathrm{Ce}^{*} \mathrm{ra}-$ tio (Figure 4). When plotted in the diagrams of [8] and [51], type 1 BIF displays neither and positive Ce anomaly (Figure 4 and Figure 5).

\subsubsection{Type 2 BIF}

The total REE + Y contents of type 2 BIF vary from 3.55 to $25.42 \mathrm{ppm}$. The light rare earth element (LREE) concentrations are higher than those of middle rare earth elements (MREE) and heavy rare earth elements (HREE) (Table 1). Type 2 BIF as well as the Kouambo BIFs have generally low absolute REE contents; which are typical of Archean to early Proetrozoic BIFs [52] [53]. 


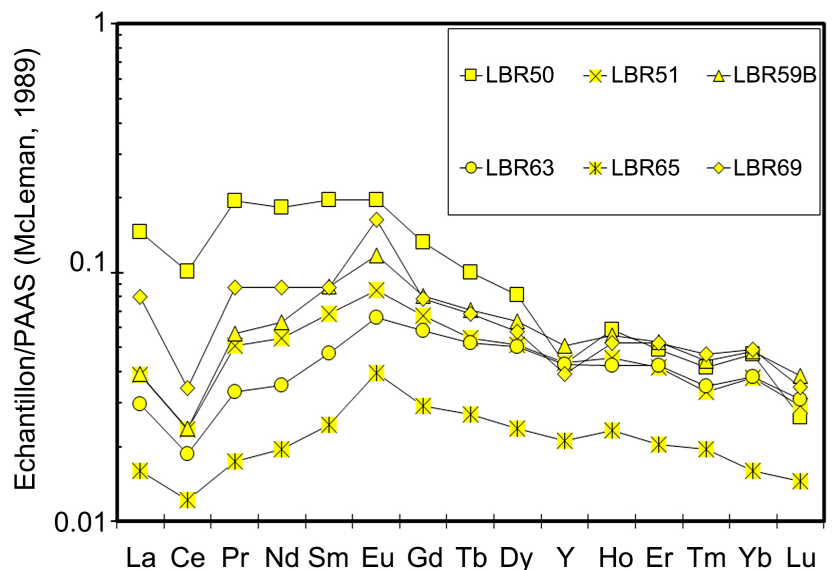

(a)

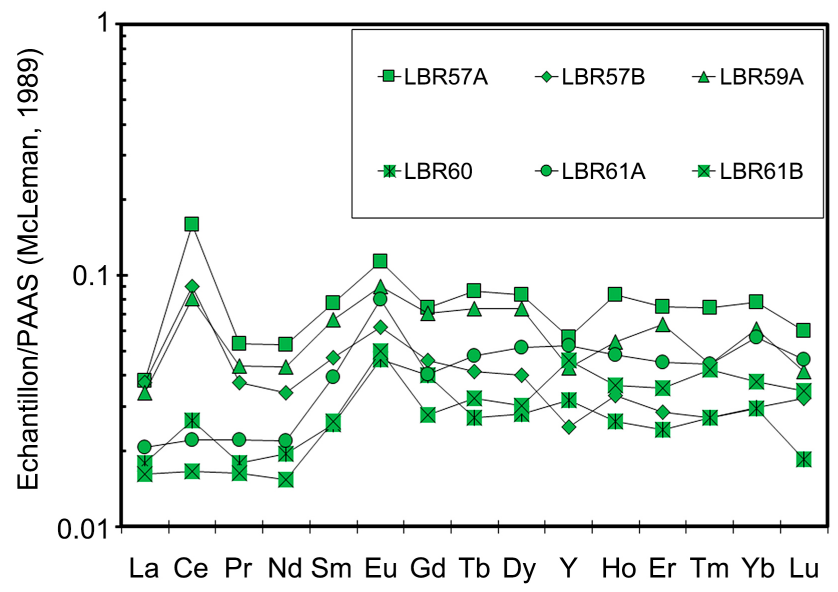

(c)

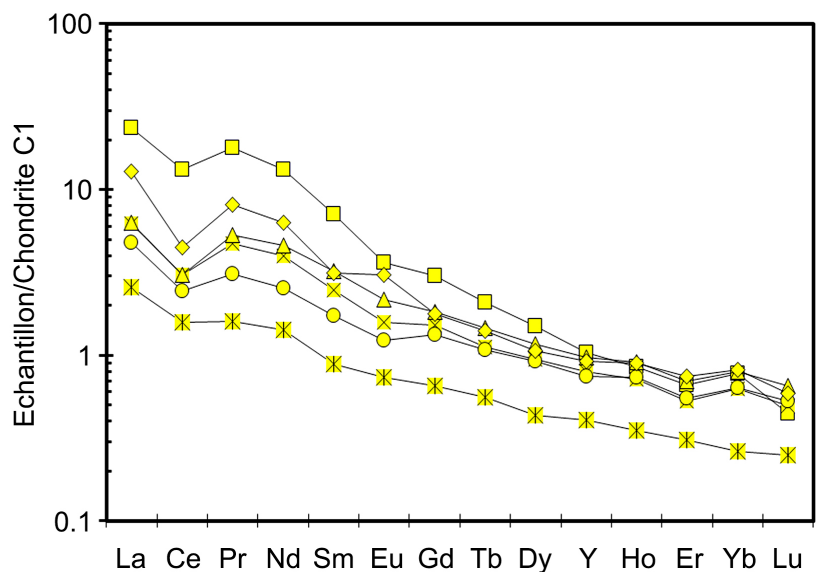

(b)

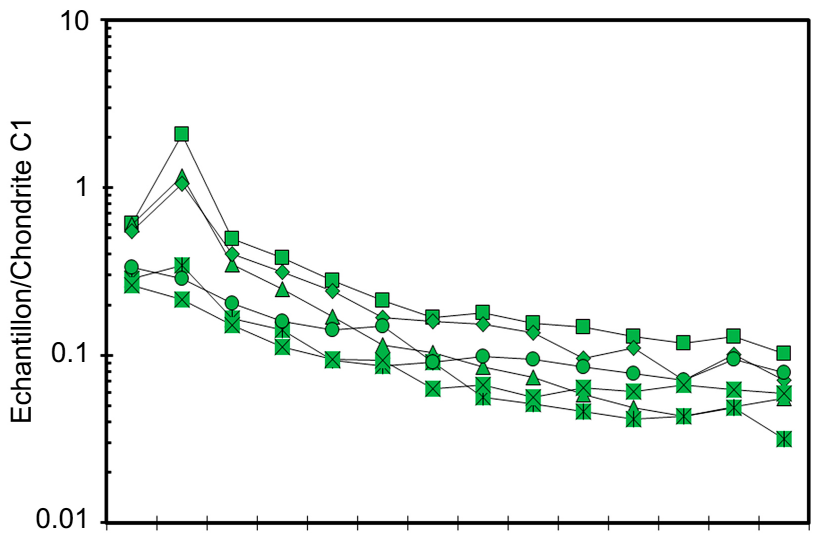

La Ce Pr Nd Sm Eu Gd Tb Dy Ho Er Tm Yb Lu

(d)

Figure 3. (a) Chondrite- and (b) Post-Archaean Australian Shale (PAAS)-normalized rare earth elements (REE) patterns of Endengue BIFs samples. Normalization value of PAAS and chondrite after [48] and [47] respectively.

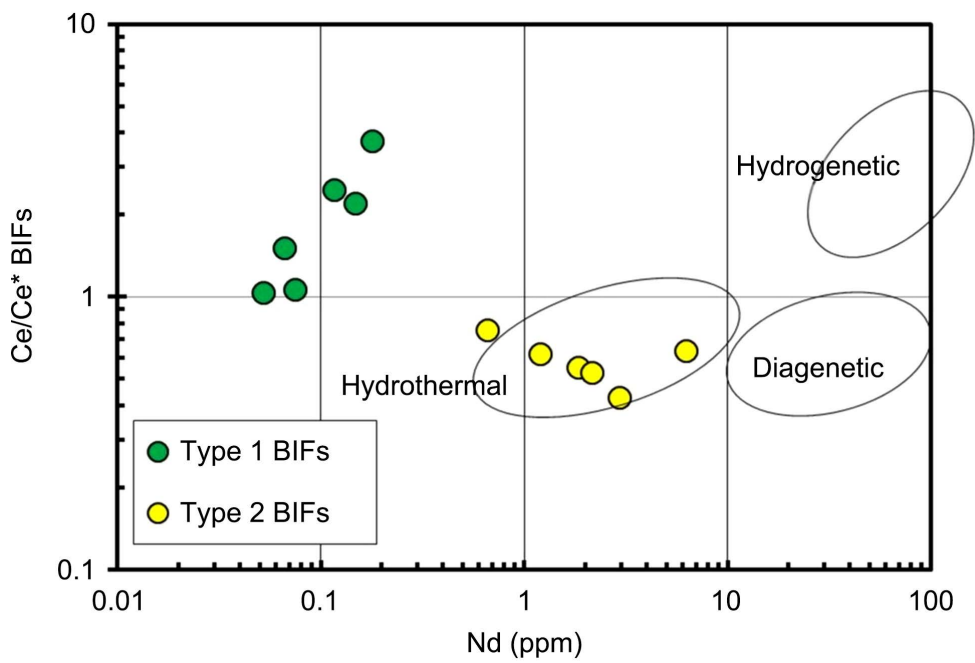

Figure 4. Graph of $\mathrm{Ce} / \mathrm{Ce}^{*}$ vs. Nd concentration for the different studied BIFs in Endengue area $\left(\mathrm{Ce} / \mathrm{Ce}^{*}=2 \mathrm{Ce}_{\mathrm{SN}} /\left(\mathrm{La}_{\mathrm{SN}}+\mathrm{Pr}_{\mathrm{SN}}\right)\right)$. The encircled areas in the graph are from [52]. 


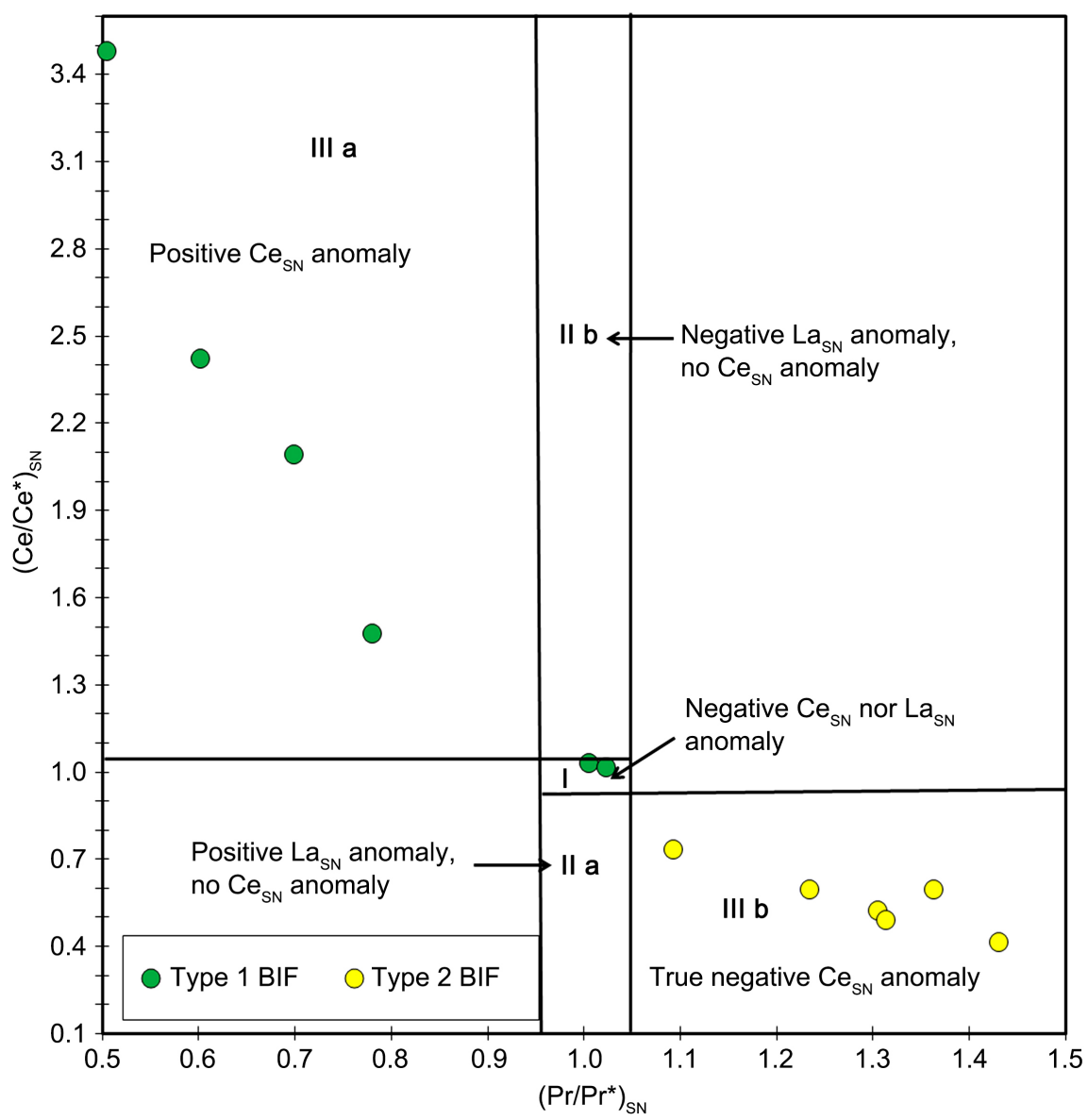

Figure 5. Discrimination diagram of $\mathrm{Ce} / \mathrm{Ce}^{\star}(\mathrm{SN})$ vs. $\operatorname{Pr} / \mathrm{Pr}^{\star}(\mathrm{SN})$ for $\mathrm{La}$ and Ce anomalies [8].

When compared to the chondrite-normalized REE diagram (Figure 3(b)), type 2 BIF displays an enrichment of LREE $\left((\mathrm{La} / \mathrm{Yb})_{\mathrm{CN}}=7.54-30.21\right)$ with negative $\mathrm{Ce}$ anomalies and depletion of HREE $\left((\mathrm{Tb} / \mathrm{Yb})_{\mathrm{CN}}=1.71-2.68\right)($ Table 1; Figure $3(\mathrm{~b}))$. They also shows weak positive Eu anomalies with $\left(\mathrm{Eu} / \mathrm{Eu}^{*}\right)_{\mathrm{CN}}$ contents which range from 0.79 and 1.29 (Table 1; Figure 3(b)). The $\mathrm{C} 1$ chondrite (Sun and McDonough, 1989) normalized REE patterns of type 2 BIF displays La, Gd, Y anomalies and superchondritic Y/Ho ratios ( $\mathrm{Y} / \mathrm{Ho}=19.80-26.17$; average: 23.92). In addition, the Archean BIFs are characterized by a HREE-enriched pattern $\left((\mathrm{Sm} / \mathrm{Yb})_{\mathrm{CN}}<1\right)[54]$ which differs from the chondrite-normalized REE diagram. Type $2 \mathrm{BIF}$ displays average $\left((\mathrm{Sm} / \mathrm{Yb})_{\mathrm{CN}}=4.52\right)$ ratio that differs from that of Eoarchean and the Mesoproterozoic BIFs.

On the PAAS-normalized REE + Y diagram (Table 1; Figure 3(d)), type 2 $\mathrm{BIF}$ is depleted in LREE relative to HREE with $(\mathrm{Tb} / \mathrm{Yb})_{S \mathrm{~N}}$ ratios ranging from 1.37 to $2.14 \mathrm{ppm}$. An interesting observation is that this BIF type shows slightly positive La, Gd, $\mathrm{Y}$ anomalies with $\left(\mathrm{La} / \mathrm{La}^{*}\right)_{\mathrm{SN}}=0.67-1.23,\left(\mathrm{Gd} / \mathrm{Gd}^{*}\right)_{\mathrm{SN}}=1-1.15$ and $\left(\mathrm{Y} / \mathrm{Y}^{\star}\right)_{S \mathrm{~S}}=0.68-0.92$ respectively, and negative Ce anomalies with $\left(\mathrm{Ce} / \mathrm{Ce}^{\star}\right)_{S \mathrm{~N}}=0.41-0.73$. Furthermore, type $2 \mathrm{BIF}$ shows enrichment in Nd contents and falls in the $1-10$ ppm ranges, except for sample LBR65 which displays 
low $\mathrm{Nd}(0.66 \mathrm{ppm})$ value and shows negative correlation between $\mathrm{Nd}$ concentration and $\mathrm{Ce} / \mathrm{Ce}^{*}$ ratio (Figure 4$) .\left(\mathrm{Ce} / \mathrm{Ce}^{*}\right)_{\mathrm{SN}}$ vs. $\left(\mathrm{Pr} / \mathrm{Pr}^{*}\right)_{\mathrm{SN}}(\mathrm{SN}$ : shale normalized) [8] and $\mathrm{Ce} / \mathrm{Ce}^{\star}$ vs. $\mathrm{Nd}$ [51] discrimination diagrams were used to further discriminate between the two types of BIFs. Using these diagrams type 1 BIF display neither and positive Ce anomaly (Figure 4 and Figure 5) whereas type 2 BIF shows negative Ce anomaly (Figure 4 and Figure 5). Both types of BIF display positive Eu anaomalies with $\left(\mathrm{Eu} / \mathrm{Eu}^{*}\right)_{\mathrm{SN}}$ (average: 1.57 and 1.42 , respectively). This weak Eu enrichment is likely indicative of a late Paleoproterozoic age for the studied BIFs [55]. In both rock types, LREE concentrations are higher than those of HREE.

\section{Discussion}

\subsection{Effects of Secondary Element Mobility}

Around the world, BIFs which are hosted in cratonic blocks are generally affected by metamorphism [56] which are related to either postdepositional thermal events, diagenesis, or weathering processes. The Endengue BIFs are metamorphosed rocks, weak to moderately foliated and coarse-grained, which reflect high-grade metamorphic conditions [57]. Thus, to evaluate the impact or effect of metamorphism in BIFs, many authors studied trace elements such as high-field strength elements (HFSE), large-ion lithophile elements (LILE) and REE with respect to their mobility. The use of high-field strength elements (HFSE) and REE can be explained by their least mobility during metamorphic processes [58]. Trace elements can be regarded as potential proxies of syn- to postdepositional processes which require some evaluation. Metamorphism has a slight to no effect on HFSE (e.g., Ti, Zr, Hf, Nb, and Ta) and REE mobility, whereas large-ion lithophile elements LILE (K, $\mathrm{Rb}, \mathrm{Cs}, \mathrm{Sr}, \mathrm{Ba}, \mathrm{Pb}, \mathrm{Th}$ and $\mathrm{U})$, are known to be mobile during diagenesis and metamorphism and thus are good indicators to detect the impact of metamorphism in BIFs [59].

The use of $\mathrm{K} / \mathrm{Rb}, \mathrm{Th} / \mathrm{U}$, and $\mathrm{La} / \mathrm{Th}$ ratios have been proposed by [60] and [59] to test the mobility effect of the LILE. The $\mathrm{K} / \mathrm{Rb}$ ratio is high in high-grade metamorphic rocks ( $>500$ for granulite) and very low in unmetamorphosed rocks (230 for igneous rock and 200 for shale) whereas the $\mathrm{Th} / \mathrm{U}$ ratios are $>4$ in high-grade metamorphic rocks, indicating $\mathrm{U}$ loss relative to Th. The average ratios of $\mathrm{K} / \mathrm{Rb}, \mathrm{Th} / \mathrm{U}$, and $\mathrm{La} / \mathrm{Th}$ in the type $1 \mathrm{BIF}$ and the type $2 \mathrm{BIF}(312.79,0.78$, $5 ; 172.13,7.68,12.29$ respectively) are similar to those of unmetamorphosed rocks. Nevertheless, the $\mathrm{Th} / \mathrm{U}(7.68>4)$ ratios observed in the type 2 BIF which indicate $\mathrm{U}$ loss relative to Th, is similar to high-grade metamorphic rocks. Several authors [54] [61] [62] suggested that hydrothermal alteration frequency decreases the REE and Sr concentration, and inversely increases the $\mathrm{Rb}$ content in rocks Type $1 \mathrm{BIF}$ is characterized by: 1 ) a low $\mathrm{Rb}$ (average: $0.17 \mathrm{ppm}$ ) and $\mathrm{Sr}$ (average $0.39 \mathrm{ppm}$ ) contents. 2) LREE-HREE depletion, and 3) weak positive Eu anomalies with average $\left(\mathrm{Eu} / \mathrm{Eu}^{*}\right)_{S \mathrm{~N}}=1.57$. In contrast, type $2 \mathrm{BIF}$ is characterized by: 1 ) a low $\mathrm{Rb}$ (average: $0.60 \mathrm{ppm}$ ) and $\mathrm{Sr}$ (average $4.23 \mathrm{ppm}$ ) contents, 2 ) 
LREE-HREE depletion, and 3) weak positive Eu anomalies with average $\left(\mathrm{Eu} / \mathrm{Eu}^{\star}\right)_{\mathrm{SN}}$ $=1.42$. These results show that the type 2 BIFs have been affected by hydrothermal alteration more than type 1 during metamorphism. All these evidences support the interpretation that the geochemical features of the Endengue BIFs were largely preserved during metamorphism and can therefore be used to constrain their origin and depositional environment of these BIFs.

\subsection{Source of Iron and Silica}

Trace elements such as $\mathrm{Zr}, \mathrm{Hf}, \mathrm{Rb}$ and $\mathrm{Sr}$ usually derived from weathering of crustal felsic rocks, while $\mathrm{Cr}, \mathrm{Ni}, \mathrm{Co}, \mathrm{V}$ and $\mathrm{Sc}$ commonly have a mafic source [63]. Typical enrichment in chemical evolved crusts is due to the low concentrations of HFSEs (e.g., Nb, Zr, Hf, U, Th and $\mathrm{Pb}$ ) [64]. The Endengue BIFs have low concentration of HFSE which suggests a little detrital input during iron precipitation. The very low contents of $\mathrm{Zr}$ in both Endengue BIFs (Table 1), could be inherited from hydrothermal solutions, which did not involve significant decoupling of $\mathrm{Y}$ from REEs. The Th/U ratio can also be used to trace the sources of contaminants in BIF [65] [66]. Likely, the syn-depositional impurities of BIFs include volcanic ash, sedimentary detritus and material of undefined source such as phosphate grains [66]. Phosphate contamination is generally associated to a $\mathrm{Th} / \mathrm{U}>5$ [66], while other impurities like clastic or volcanic are expressed by $\mathrm{Th} / \mathrm{U}$ ratio of ca. 3 - 5 [65] [66]. Thus, the assimilation of phosphates in iron formation increases the $\mathrm{Th} / \mathrm{U}$ ratio. Type 2 BIF samples have $\mathrm{Th} / \mathrm{U}$ ratios that vary from 0.51 to 2.48 , except for sample LBR50 with Th/U ratio of 28.3. This result suggests high phosphate contamination in type $2 \mathrm{BIF}$. In contrast, type 1 $\mathrm{BIF}$ has extreme low $\mathrm{Th} / \mathrm{U}$ ratio that lies between 0.093 - 1.79 (0.78 in average) showing no phosphate, clastic or volcanic contaminations. In addition, [67] used $\mathrm{Co} / \mathrm{Zn}$ ratio as a tracer of hydrothermal input. Low Co/Zn (0.15) ratio characterizes hydrothermal deposits, while high $\mathrm{Co} / \mathrm{Zn}$ ratio (2.5) indicates hydrogenous deposits. The average $\mathrm{Co} / \mathrm{Zn}$ ratio is 0.25 for type $1 \mathrm{BIF}$ samples and 0.26 for type 2 BIF samples, similarly to Elom BIFs (0.3). This could suggest that the iron and silica of these BIFs have a hydrothermal source.

\subsection{Discrimination of Types of BIFs and Interpretation Based on REE + Y Content}

Rare earth elements can be used to proper understand the origin of the forming fluids as they are not easily fractionated during sedimentation ([44] [47] [51] [68], and references herein). In addition, REEs + Y in BIF are usually regarded as being immobile during most geologic processes and have been found to be only of insignificant importance in most cases [8] [69].

The $\Sigma$ REE concentrations of the type 2 BIF $(2.98-24.26 \mathrm{ppm}, 9.45 \mathrm{ppm}$ in average) and type 1 BIF (0.34 - $1.83 \mathrm{ppm}, 0.88 \mathrm{ppm}$ in average) (Table 1) samples fall within the range of hydrothermal origin (15 - $149 \mathrm{ppm}$ ) as reported by [51]. Type 2 BIF has high REEs contents compared to type $1 \mathrm{BIF}$, which is indic- 
ative of some contribution from the associated siliciclastic sediments during their formation. The negative $\mathrm{Ce}$ and $\mathrm{Y}$ anomalies, positive Eu anomaly and the low Nd concentrations (1 - 10 ppm, except for LBR65 sample with $0.67 \mathrm{ppm}$ ), together with low concentration of REE in type 2 BIF samples strongly suggest a hydrothermal origin for this BIF type (Figure 4 and Figure 5). Type 1 BIF samples show positive $\mathrm{Ce}$ and $\mathrm{Eu}$ anomaly, negative $\mathrm{Y}$, extremely low concentration of Nd (0.01 - 1 ppm) and REEs (0.45 - $1.99 \mathrm{ppm})$. All these features mostly likely indicate the hydrothermal origin of the studied BIFs (Figure 4 and Figure 5). Therefore, the presence of positive $\mathrm{Y}$ anomalies in both type 2 and type 1 BIFs suggests that precipitation of Fe-Mn minerals occurred very rapidly and immediately after reducing, slightly acidic waters mixed with more oxidizing and more alkaline water [8]. The weak positive Eu anomaly of type 1 BIF might be a signature inherited from hydrothermal solutions that lost their positive Eu anomaly because of a relatively high oxygen level [70]. This interpretation is strengthened by the fact that, in modern oceans, high-temperature hydrothermal solutions lose their Eu anomaly due to rapid oxidation of $\mathrm{Eu}$ as a consequence of mixing with oxidized seawater [71]. The higher Eu anomaly in type 1 BIFs compared to the type 2 BIFs provides further evidence that significantly more REE + $\mathrm{Y}$ input from hydrothermal solutions was involved in the formation of type 1 BIFs. Therefore, the REE $+\mathrm{Y}$ values support the hydrothermal origin for the both BIFs [57].

In order to constrain the degree of influence of seawater, in BIF, [72] and [66] have proposed the use of $\mathrm{La} / \mathrm{La}^{*}, \mathrm{Y} / \mathrm{Ho}$ and $(\mathrm{Nd} / \mathrm{Yb})_{\mathrm{SN}}$ ratios: 1$) \mathrm{La} / \mathrm{La}^{*}$ constrains the strength of La anomaly caused by seawater precipitation; 2) Y/Ho measures the enrichment or depletion of $\mathrm{Y}$ from chondritic values, i.e., a measurement of hydrogenous processes; 3$)(\mathrm{Nd} / \mathrm{Yb})_{S \mathrm{~N}}$ indicates the HREE fractionation in BIF, as these elements are not fractionated compared to the LREE-neighbors. Therefore, [8] [66] [73] have assigned positive La, Gd and Y anomalies, superchondritic Y/Ho ratios of 40 to 90, and LREE depletion to modern seawater reported for hydrogenous sediments. The PAAS-normalized REE + Y of the Endengue BIFs (this study) indicate slightly LREE-depleted and positive La, Gd and Y anomalies. Moreover, chrondritic Y/Ho ratios (27) have been attributed to hydrothermal solutions and constant Y/Ho ratio ( 26) to terrestrial material (e.g., felsic and basaltic crust) [9] [10]. In our case, both type 1 and type 2 BIFs display low Y/Ho ratio (26.16 and 23.92, respectively), which are similar to terrestrial material. According to [9] the low Y/Ho ratio is related to a small mixture of terrestrial material to chemical precipitate from seawater.

A high-temperature hydrothermal alteration produces fluids with a pronounced positive $\mathrm{Eu}$ anomaly; while fluids produced by low-temperature hydrothermal alteration have a weak or no Eu anomaly [74]. Both type 1 and type 2 BIFs display weak positive $\mathrm{Eu}$ anomalies $\left(\mathrm{Eu} / \mathrm{Eu}^{\star}=1.57\right.$ and 1.42 , respectively) and HREE enrichment $\left((\mathrm{Tb} / \mathrm{Yb})_{S \mathrm{~N}}=2.91\right.$ and 1.59 , respectively), similar to the REE patterns of the Archean to early Paleoproterozoic BIFs. The HREE-enrichment 
relative to LREE in these BIFs is a feature inherited from seawater, while the small positive Eu anomaly is inherited from low-temperature hydrothermal solutions. This is likely attributed to the source not only of the REEs but also of Fe and $\mathrm{Si}$ [48]. The negative $\mathrm{Ce}$ anomalies with positive Eu anomalies in the type 2 BIF suggest rapid precipitation of the hydrothermal Fe load in the presence of sufficiently oxygenated shallow waters [75] similar to Kouambo BIFs deposit hosted in Paleoproterozoic Nyong group [76]. [53] has proposed that HREE-enrichment in PASS-normalized patterns for some iron formations associated with volcanic rocks is possibly inherited from a mafic volcanic source, following relatively low-temperature seawater-rock interaction.

PAAS [47] normalized REE + Y patterns of the Endengue BIFs and other BIFs worldwide (Ngovayang, Elom, Kouambo, Jocadigo and Kuruman) are presented in (Figure 6). This diagram shows that the REE $+\mathrm{Y}$ patterns of type 2 BIFs are similar to the Kouambo BIFs from Nyong group in SW Cameroon [76] and low-T hydrothermal fluids profiles. The Jocadigo BIFs of SW Brazil [77], and type 2 BIF share similar profiles, although the negative Eu anomaly is absent in our case. In addition, the modern seawater and Kuruman BIFs with the exception of the positive $\mathrm{Y}$ anomaly also share the same trend. On the other hand, type 2 BIF displays weak Eu anomaly and REE-depletion when compared to the Neoarchean Ngovayang IF from SW Cameroon [78] and the average composition of the high temperature hydrothermal fluids. Consequently, type 2 BIF REE $+\mathrm{Y}$ patterns indicate a deposition environment characterized by the mixture of seawater and low-temperature hydrothermal fluids.

The REE + Y patterns of type 1 BIF display close similarities with the Elom BIFs from Ntem group in SW Cameroon [16] which are located some $10 \mathrm{Km}$ North of the Endengue area. These patterns are generally different from those of the Jocadigo BIFs, but are closely similar to Neoarchean Ngovayang IF with no Ce and weak positive Eu anomalies (Figure 6). In addition, type 1 BIFs with weak positive Eu anomaly are similar to low-T hydrothermal fluids, and Kuruman BIFs (with the exception of the negative Ce anomaly and the positive $\mathrm{Y}$ anomaly). Conversely, type 1 BIF shows REE-depletion and weak positive Eu relative to low-T hydrothermal fluids. All these features indicate that e type 1 BIF were deposited in redox stratified ocean in a reducing environment, probably in the suboxic or anoxic seawaters in the presence of the low-temperature hydrothermal solutions.

\subsection{Depositional Environment}

Various depositional environments and setting including open anoxic marine basins, continental shelves, isolated platforms and sealed basins were proposed for the precipitation of iron and silica [79]. Due to its sensitivity to oxygen and the large difference in the solubility of its ion, cerium is a good proxy for redox state of seawater [80]. When normalized to PAAS, Ce in an oxygenated marine environment shows a strong negative Ce anomaly, while suboxic and anoxic 


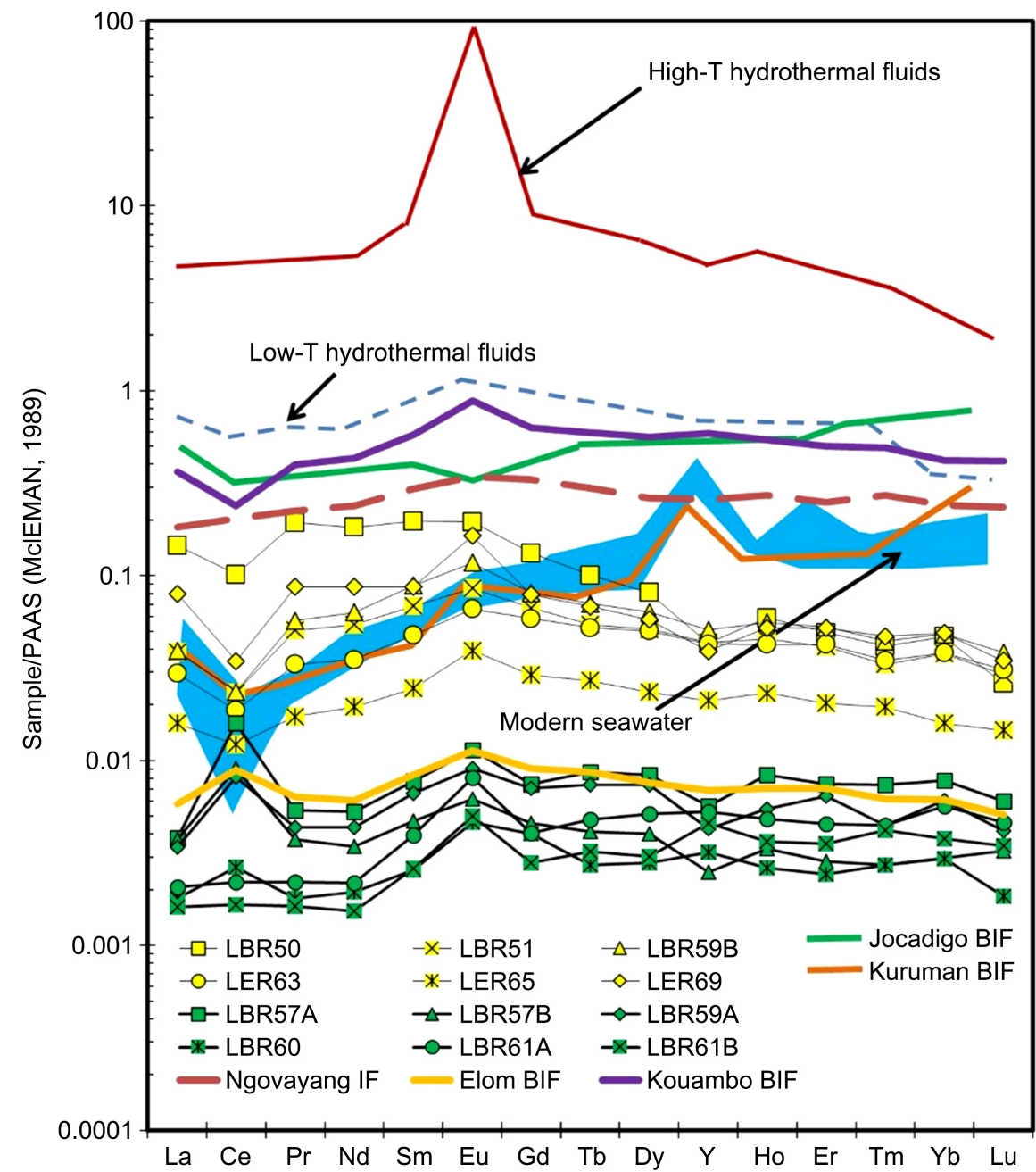

Figure 6. PAAS-normalized REE-Y patterns of the Endengue BIFs compared with the average compositions of hydrothermal fluids [10], modern seawater [11], and others well-studied BIFs worldwide including: 1) the Neoarchean Ngovayang iron formation (IF) from SW Cameroon, BIFs from SW Greenland [11]; 2) the Kuruman BIFs, the Elom BIFs and the Kouambo BIFs from SW Cameroon [16] [75]; and 3) the Neoproterozoic Jocadigo BIFs of SW Brazil [76].

water, are expected to have no or locally positive Ce anomaly [80] [81] [82]. Consequently, the Ce depletion is obvious for the distribution patterns of dissolved REEs under oxic conditions. Conversely no depletion or even Ce enrichment occurs in anoxic conditions [70]. ( $\left.\mathrm{Ce} / \mathrm{Ce}^{\star}-\mathrm{Pr} / \mathrm{Pr}^{\star}\right)[8]$ and $\mathrm{Ce} / \mathrm{Ce}^{\star}$ vs $\mathrm{Nd}$ [51] diagrams have been proposed to discriminate "true" from "false" Ce anomalies. In these plots (Figure 4 and Figure 5), type 2 BIF samples plot in the field of true negative $\mathrm{Ce}_{\mathrm{SN}}$ anomalies, indicating oxidized environment for their precipitation. In other hand, the negative Ce anomalies can suggest suboxic conditions where aqueous $\mathrm{Ce}^{3+}$ is depleted [83]. The negative Ce anomalies can also be compatible with the geological evidence for shallow-marine environment [75], which is consistent with their HREE enrichment relative to LREE in PAASnormalized diagram (Figure 4). Moreover, the comparative PAAS-normalized 
diagram (Figure 6) show similar $\mathrm{Ce}$ and Eu anomalies with Kouambo BIFs, but different from the Elom and Jocadigo BIFs. In the same diagram, type 1 BIF samples were also plotted and most samples (except samples LBR61A and LBR61B) fall in the field of true positive $\mathrm{Ce}_{\mathrm{SN}}$ anomalies (Figure 4 and Figure 5). The true positive Ce anomalies are associated to the strongly anoxic conditions, favorable to the precipitation of ferrous metals [84]. In addition, the positive anomalies in cerium result from a change of valence of cerium from +3 to +4 as consequences of hydrothermal effects [85] [86]. This indicates a dissolved positive $\mathrm{Ce}$ anomaly which occurs in the fluctuation of $\mathrm{pH}$, which is appropriated to marine conditions [9] [87]. Type 1 BIFs, have average $\mathrm{Y} / \mathrm{Ho}$ ratios of 26.17, which are low than the Ngovayang IF (average Y/Ho ratio of 28.65); Elom BIFs (average Y/Ho ratio of 28); Archean-Early Paleoproterozoic BIFs (average Y/Ho ratio of 39), and the Late Paleoproterozoic BIFs (average Y/Ho ratio of 32; [55]). Nevertheless, these samples are slightly LREE-enriched and HREE-depleted, similar to the Elom BIFs, indicating the simultaneous deposition of type 1 BIF with the change in oxidation-reduction status of seawater, probably during the Great Oxidation Event (GOE).

When comparing some concentrations of transition metals like $\mathrm{Zn}, \mathrm{Cu}, \mathrm{Ni}$, Co and V of our samples to other IFs around the world, both studied BIFs are obviously depleted in $\mathrm{Zn}, \mathrm{Cu}, \mathrm{Ni}, \mathrm{Co}$ and $\mathrm{V}$ (Table 1), similar to transition metals contents in Elom and Superior-type BIFs. The positive and negative Ce anomalies are characterized by early to late Paleoproterozoic BIFs [55] [88]. [89] proposed that $\mathrm{Eu} / \mathrm{Sm}$ ratio can be used to differentiate the Archean $(0.40-1.22)$ and Proterozoic $(0.24-0.40)$ BIFs. The Eu/Sm ratio of the type 1 BIF lies between 0.26 to 0.40 and the type 2 BIFs varies from 0.19 to 0.37 . The Paleoproterozoic BIFs differ from Archean ones in the lower contents of $\mathrm{Ni}, \mathrm{Cr}, \mathrm{Co}$, and $\mathrm{Zn}$ [41] which is consistent with the both types of studied BIFs. Previous studies have proposed that the greenstone terranes of Ntem complex are Mesoarchean in age [36]. Type $1 \mathrm{BIF}$ with Eu/Sm ratio of 0.26 to 0.40 were probably precipitated during early Paleoproterozoic, while type $2 \mathrm{BIF}$ with $\mathrm{Eu} / \mathrm{Sm}$ ratios of 0.19 to 0.37 were precipitated during late Paleoproterozoic period similar to Kouambo BIFs and the Kpwa-Atog Boga BIFs within the Paleoproterozoic Nyong group.

The two BIF types have LREE-enrichment relative to HREE, suggesting an oxidizing deposition environment. According to [76], the chondrite-normalized REE patterns display LREE enrichment $(3<\mathrm{La} / \mathrm{Yb}<30)$ and HREE depletion, low $\mathrm{Nb} / \mathrm{Y}(<0.3)$ and $\mathrm{Ti} / \mathrm{V}(<500)$ ratios, suggesting continental marginal sea or back-arc basin basalt. Both Endengue BIFs present LREE enrichment $(4.74<$ $\mathrm{La} / \mathrm{Yb}<31.536$ ) and HREE depletion, extreme low $0.086 \mathrm{Nb} / \mathrm{Y}$ and $0.12 \mathrm{Ti} / \mathrm{V}$ ratios for the type 1 BIF; LREE enrichment $(7.54<\mathrm{La} / \mathrm{Yb}<30.214)$ and HREE depletion, average $0.13 \mathrm{Nb} / \mathrm{Y}$ and $0.2 \mathrm{Ti} / \mathrm{V}$ ratios for type $2 \mathrm{BIF}$, suggest a continental marginal sea or back-arc basin basalt deposit. In addition, rocks which formed in the rift and residual sea setting are enriched in LREE due to their proximity to the continent, though those which formed in mid-oceanic ridge 


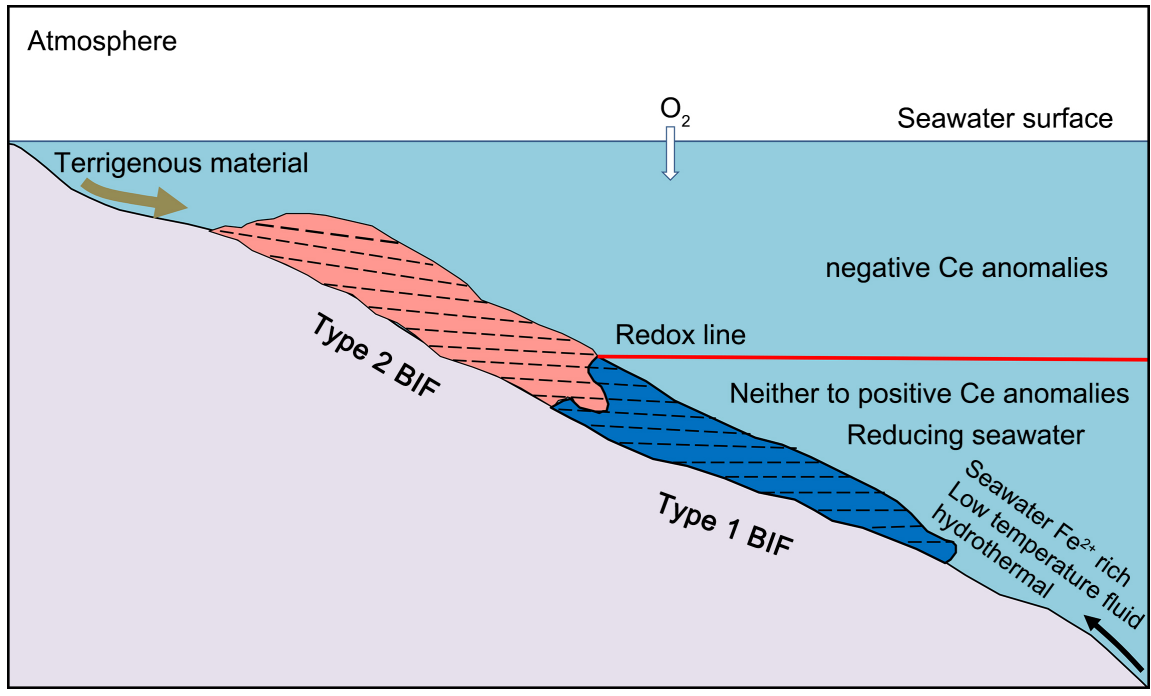

Figure 7. Schematic depositional model of the Endengue BIFs.

and deep-sea environment are characterized by LREE-depletion [90]. The Endengue BIFs show apparent chemical features of contamination by terrestrial material (LREE enrichment) as mentioned above. Geochemical features with low REEs contents and positive Eu anomalies are considered as evidence of hydrothermal fluid circulation in the bottom layer of marine basins [42] [48] [54] [56] [91] [92] [93]. The Ti/V ratios of the studied samples are closer to ferruginous shales $(1.33$ - 10.9). The deposition of the Endengue BIFs can be under the influence of low-temperature which drops the concentration of some traces elements.

From the above observation, the Endengue BIFs were probably deposited in a continental marginal sea environment where oxidized and reduced shallow seawater mixed with low-temperature hydrothermal fluids contributed to the precipitation of its chemical components (Fe and $\mathrm{Si}$ ) (Figure 7) like the Changyi BIFs situated within the North China Craton [59], Elom BIFs located within the Ntem group in SW Cameroon [16], the Kouambo BIFs and the Kpwa-Atog Boga BIFs located within the Nyong group in SW Cameroon [76] [88].

\section{Conclusion}

The Endengue Banded Iron Formations (BIFs) have low contents of trace and rare earth elements. These BIFs further have a little detritus-free iron which is most likely the source of iron and silica. However, both BIFs are mostly related to hydrothermal fluid and continental marginal sea. The source of silica is probably derived from the continental crust similarly to the Elom BIFs in south Cameroon (type $1 \mathrm{BIF}$ ) and Superior type BIFs (type $2 \mathrm{BIF}$ ). The negative Ce anomalies with positive $\mathrm{Eu}$ anomalies and moderate $\mathrm{Nd}$ contents (1 - $100 \mathrm{ppm})$ with negative correlation between $\mathrm{Nd}$ versus $\mathrm{Ce} / \mathrm{Ce}^{\star}$ ratio in the type $2 \mathrm{BIF}$ provide evidence of rapid precipitation of the hydrothermal Fe load in the presence of sufficiently oxygenated shallow water. In contrast, the positive Ce anomalies 
with positive Eu anomalies and low $\mathrm{Nd}$ contents $(<1 \mathrm{ppm})$ and positive correlation between $\mathrm{Nd}$ versus $\mathrm{Ce} / \mathrm{Ce}^{\star}$ ratio in the type $1 \mathrm{BIF}$ indicate an intense remobilization with an inherited $\mathrm{Fe}$ from marine bottom through the contribution of hydrothermal solutions in the strongly oxidizing condition. The weak positive $\mathrm{Eu}$ anomalies of the studied BIFs suggest an essential role of low-temperature hydrothermal solutions. The absence and positive Ce anomalies, the Eu/Sm ratios (0.26 to 0.40$)$ with the low transition metals contents, in the type 1 BIF suggest their precipitation during early Paleoproterozoic time. Conversely, the negative $\mathrm{Ce}$ anomalies, the $\mathrm{Eu} / \mathrm{Sm}$ ratios (0.19 to 0.37 ) and the low transition metals contents in the type 2 BIF indicate their precipitation during late Paleoproterozoic period similar to Kouambo BIFs and Kpwa-Atog Boga BIFs within the Paleoproterozoic Nyong group. The geochemical features of Endengue BIFs are consistent with the depositional environment of the continental marginal sea, in presence of low-temperature hydrothermal solutions mixed with seawater. This depositional setting is similar to the Kpwa-Atog Boga BIFs located within the Paleoproterozoic Nyong group in SW Cameroon, the Elom BIFs located within the Archean Ntem group in SW Cameroon and Paleoproterozoic Superior type BIFs worldwide.

\section{Acknowledgements}

This study is part of the $\mathrm{PhD}$ work of the first author at the University of Dschang. The authors gratefully acknowledge the mineral exploration company Divine Mining Ltd. for logistic support during the field trip. This is a contribution to the IGCP 646 project.

\section{Conflicts of Interest}

The authors declare no conflicts of interest regarding the publication of this paper.

\section{References}

[1] James, H.L. (1954) Sedimentary Facies of Iron-Formations. Economic Geology, 49, 235-293. https://doi.org/10.2113/gsecongeo.49.3.235

[2] Trendall, A.F. (1983) Introduction. In: Trendall, A.F. and Morris, R.C., Eds., Developments in Precambrian Geology, Elsevier, Amsterdam, 1-12. https://doi.org/10.1016/S0166-2635(08)70040-9

[3] Heim, C., Simon, K., Ionescu, D., Reimer, A., De Beer, D., Quéric, N.V., Reitner, J. and Thiel, V. (2015) Assessing the Utility of Trace and Rare Earth Elements as Biosignatures in Microbial Iron Oxyhydroxides. Frontiers in Earth Sciences, 3, 6. https://doi.org/10.3389/feart.2015.00006

[4] Fryer, B.J. (1971) Canadian Precambrian Iron-Formations: Ages and Trace Element Compositions. PhD Thesis, Massachusetts Institute of Technology, Cambridge, MA, 175.

[5] Balaram, V., Manikyamba, C., Ramesh, S.L. and Anjaiah, K.V. (1992) Rare Earth and Trace Element Determination in Iron-Formation Reference Samples by ICP-MS. National Geophysical Research Institute, Hyderabad, India, 19-25. 
[6] Bolhar, R., Hofmann, A., Woodhead, J., Hergt, J. and Dirks, P. (2002) Pb- and Nd Isotope Systematics of Stromatolitic Limestones from the $2.7 \mathrm{Ga}$ Ngezi Group of the Belingwe Greenstone Belt: Constraints on Timing of Deposition and Provenance. Precambrian Research, 114, 277-294. https://doi.org/10.1016/S0301-9268(01)00229-7

[7] Van Kranendonk, M.J., Webb, G.E. and Kamber, B.S. (2003) Geological and Trace Element Evidence for a Marine Sedimentary Environment of Deposition and Biogenicity of $3.45 \mathrm{Ga}$ Stromatolitic Carbonates in the Pilbara Craton, and Support for a Reducing Archaean Ocean. Geobiology, 1, 91-108.

https://doi.org/10.1046/j.1472-4669.2003.00014.x

[8] Bau, M. and Dulski, P. (1996) Distribution of Yttrium and Rare-Earth Elements in the Penge and Kuruman Iron-Formations, Transvaal Supergroup, South Africa. Precambrian Research, 79, 37-55. https://doi.org/10.1016/0301-9268(95)00087-9

[9] Bau, M. and Dulski, P. (1999) Comparing Yttrium and Rare Earths in Hydrothermal Fluids from the Mid-Atlantic Ridge: Implications for Y and REE Behaviour during Near Vent Mixing and for the Y/Ho Ratio of Proterozoic Seawater. Chemical Geology, 155, 77-90. https://doi.org/10.1016/S0009-2541(98)00142-9

[10] Bolhar, R., Kamber, B.S., Moorbath, S., Fedo, C.M. and Whitehouse, M.J. (2004) Characterization of Early Archean Chemical Sediments by Trace Element Signatures. Earth and Planetary Science Letters, 222, 43-60.

https://doi.org/10.1016/j.epsl.2004.02.016

[11] Wang, Y.H., Zhang, F.F., Liu, J.J. and Que, C.Y. (2016) Genesis of the Fuxing Porphyry $\mathrm{Cu}$ Deposit in Eastern Tianshan, China: Evidence from Fluid Inclusions and C-H-O-S-Pb Isotope Systematics. Ore Geology Reviews, 79, 46-61. https://doi.org/10.1016/j.oregeorev.2016.04.022

[12] Elderfield, H. (1988) The Oceanic Chemistry of the Rare-Earth Elements. Philosophical Transactions of the Royal Society of London, 325, 105-106. https://doi.org/10.1098/rsta.1988.0046

[13] Piepgras, D.J. and Jacobsen, S.B. (1992) The Behavior of Rare Earth Elements in Seawater: Precise Determination of Variations in the North Pacific Water Column. Geochimica et Cosmochimica Acta, 56, 1851-1862. https://doi.org/10.1016/0016-7037(92)90315-A

[14] Webb, G.E. and Kamber, B.S. (2000) Rare Earth Elements in Holocene Reefal Microbialites: A New Shallow Seawater Proxy. Geochimica et Cosmochimica Acta, 64, 1557-1565. https://doi.org/10.1016/S0016-7037(99)00400-7

[15] Ilouga, C.D.I., Suh, C.E. and Ghogomu, R.T. (2013) Textures and Rare Earth Elements Composition of Banded Iron Formations (BIF) at Njweng Prospect, Mbalam Iron Ore District, Southern Cameroon. International Journal of Geosciences, 4, 146-165. https://doi.org/10.4236/ijg.2013.41014

[16] Ganno, S., Ngnotue, T., Kouankap, N.G.D., Nzenti, J.P. and Notsa, F.M. (2015) Petrology and Geochemistry of the Banded Iron-Formations from Ntem Complex Greenstones Belt, Elom Area, Southern Cameroon: Implications for the Origin and Depositional Environment. Geochemistry, 75, 375-387.

https://doi.org/10.1016/j.chemer.2015.08.001

[17] Teutsong, T., Bontognali, T.R.R., Ndjigui, P.D., Vrijmoed, J.C., Teagle, D., Cooper, M. and Vance, D. (2017) Petrography and Geochemistry of the Mesoarchean Bikoula Banded Iron Formation in the Ntem Complex (Congo Craton), Southern Cameroon: Implications for Its Origin. Ore Geology Reviews, 80, 267-288.

https://doi.org/10.1016/j.oregeorev.2016.07.003 
[18] Ndime, E.N., Ganno, S., Tamehe, L.S. and Nzenti, J.P. (2018) Petrography, Lithostratigraphy and Major Element Geochemistry of Mesoarchean Metamorphosed Banded Iron Formation-Hosted Nkout Iron Ore Deposit, North Western Congo Craton, Central West Africa. Journal of African Earth Sciences, 148, 80-98. https://doi.org/10.1016/j.jafrearsci.2018.06.007

[19] Maurizot, P., Abessolo, A., Feybesse, J.L. and Johan, L.P. (1986) Étude de prospection minière du Sud-Ouest Cameroun, Synthèse des travaux de 1978 à 1985, Rapport de BRGM 85, 274.

[20] Toteu, S.F., Van Schmus, W.R., Penaye, J. and Nyobe, J.B. (1994) U-Pb and Sm-Nd Evidence for Eburnian and Pan-African High-Grade Metamorphism in Cratonic Rocks of Southern Cameroon. Precambrian Research, 67, 321-347. https://doi.org/10.1016/0301-9268(94)90014-0

[21] Toteu, S.F., Van Schmus, W.R., Penaye, J. and Michard, A. (2001) New U-Pb, and Sm-Nd Data from North-Central Cameroon and Its Bearing on the Pre-Pan-African History of Central Africa. Precambrian Research, 108, 45-73. https://doi.org/10.1016/S0301-9268(00)00149-2

[22] Pouclet, A., Tchameni, R., Mezger, K., Vidal, M., Nsifa, E., Shang, C. and Penaye, J. (2007) Archaean Crustal Accretion at the Northern Border of the Congo Craton (South Cameroon). The Charnockite-TTG Link. Bulletin de la Société Géologique de France, 178, 331-342. https://doi.org/10.2113/gssgfbull.178.5.331

[23] Suh, C.E., Cabral, A.R., Shemang, E.M., Mbinkar, L. and Mboudou, G.G.M. (2008) Two Contrasting Iron Deposits in the Precambrian Mineral Belt of Cameroon, West Africa. Exploration and Mining Geology, 17, 197-207. https://doi.org/10.2113/gsemg.17.3-4.197

[24] Tchameni, R., Mezger, K., Nsifa, N.E. and Pouclet, A. (2000) Neoarchaean Evolution in the Congo Craton: Evidence from K Rich Granitoids of the Ntem Complex, Southern Cameroon. Journal of African Earth Sciences, 30, 133-147. https://doi.org/10.1016/S0899-5362(00)00012-9

[25] Shang, C.K., Satir, M., Siebel, W., Nsifa, E.N., Taubald, H., Liegeois, J.P. and Tchoua, F.M. (2004) TTG Magmatism in the Congo Craton; A View from Major and Trace Element Geochemistry, Rb-Sr and Sm-Nd Systematics: Case of the Sangmelima Region, Ntem Complex, Southern Cameroon. Journal of African Earth Sciences, 40, 61-79. https://doi.org/10.1016/j.jafrearsci.2004.07.005

[26] Nédélec, A., Nsifa, E.N. and Martin, H. (1990) Major and Trace Element Geochemistry of the Archaean Ntem Plutonic Complex (South Cameroon): Petrogenesis and Crustal Evolution. Precambrian Research, 47, 35-50. https://doi.org/10.1016/0301-9268(90)90029-P

[27] Shang, C.K., Satir, M., Siebel, W., Taubald, H., Nsifa, E.N., Westphal, M. and Reitter, E. (2001) Genesis of K-Rich Granitoids in the Sangmelima Region, Ntem Complex (Congo Craton), Cameroon. Terra Nostra, 5, 60-63.

[28] Shang Siebel, W., Satir, M., Chen, F. and Mvondo, J.O. (2004) Zircon Pb-Pb and $\mathrm{U}-\mathrm{Pb}$ Systematics of TTG Rocks in the Congo Craton: Constraints on Crust Formation, Magmatism, and Pan-African Lead Loss. Bulletin of Geosciences, 79, 205-219.

[29] Tchameni, R., Lerouge, C., Penaye, J., Cocherie, A., Milesi, J.P., Toteu, S.F. and Nsifa, E.N. (2010) Mineralogical Constraint for Metamorphic Conditions in a Shear Zone Affecting the Archean Ngoulemakong Tonalite, Congo Craton (Southern Cameroon) and Retentivity of U-Pb SHRIMP Zircon Dates. Journal of African Earth Sciences, 58, 67-80. https://doi.org/10.1016/j.jafrearsci.2010.01.009

[30] Li, X.H., Chen, Y., Li, J., Yang, C., Ling, X.X. and Tchouankoue, J.P. (2016) New 
Isotopic Constraints on Age and Origin of Mesoarchean Charnockite, Trondhjemite and Amphibolite in the Ntem Complex of NW Congo Craton, Southern Cameroon. Precambrian Research, 276, 14-23. https://doi.org/10.1016/j.precamres.2016.01.027

[31] Takam, T., Arima, M., Kokonyangi, J., Dunkley, D.J. and Nsifa, E.N. (2009) Paleoarchaean Charnockite in the Ntem Complex, Congo Craton, Cameroon: Insights from SHRIMP Zircon U-Pb Ages. Journal of Mineralogical and Petrological Sciences, 104, 1-11. https://doi.org/10.2465/jmps.080624

[32] Tchameni, R., Pouclet, A., Mezger, K., Nsifa, N.E. and Vicat, J.P. (2004) Single Zircon $\mathrm{Pb}-\mathrm{Pb}$ and $\mathrm{Sm}-\mathrm{Nd}$ Whole Rock Ages for the Ebolowa Greenstone Belts: Evidence for Pre-2.9 Ga Terranes in the Ntem Complex (South Cameroon). Journal of the Cameroon Academy of Sciences, 4, 235-246.

[33] Ganno, S., Tsozué, D., Kouankap, N.G.D., Tchouatcha, M.S., Ngnotué, T., Gamgne Takam, R. and Nzenti. J.P. (2018) Geochemical Constraints on the Origin of Banded Iron Formation-Hosted Iron Ore from the Archaean Ntem Complex (Congo Craton) in the Meyomessi Area, Southern Cameroon. Resource Geology, 68, 287-302. https://doi.org/10.1111/rge.12172

[34] Ndime, E.N., Ganno, S. and Nzenti, J.P. (2019) Geochemistry and Pb-Pb Geochronology of the Neoarchean Nkout West Metamorphosed Banded Iron Formation, Southern Cameroon. International Journal of Earth Sciences, 108, 1551-1570. https://doi.org/10.1007/s00531-019-01719-5

[35] Shang, C.K., Satir, M., Nsifa, E.N., Liégeois, J.P., Siebel, W. and Taubald, H. (2007) Archaean High-K Granitoids Produced by Remelting of Earlier Tonalite-Trondhjemite-Granodiorite (TTG) in the Sangmelima Region of the Ntem Complex of the Congo Craton, Southern Cameroon. International Journal of Earth Sciences, 96, 817-841. https://doi.org/10.1007/s00531-006-0141-3

[36] Shang, C.K., Liégeois, J.P., Satir, M., Frisch, W. and Nsifa, E.N. (2010) Late Archaean High-K Granite Geochronology of the Northern Metacratonic Margin of the Archaean Congo Craton, Southern Cameroon: Evidence for Pb-Loss Due to Non-Metamorphic Causes. Gondwana Research, 18, 337-355.

[37] Akame, J.M., Oliveira, E.P., Poujol, M., Hublet, G. and Debaille, V. (2020) LA-ICP-MS Zircon U-Pb Dating, Lu-Hf, Sm-Nd Geochronology and Tectonic Setting of the Mesoarchean Mafic and Felsic Magmatic Rocks in the Sangmelima Granite-Greenstone Terrane, Ntem Complex (South Cameroon). Lithos, 372-373, Article ID: 105702. https://doi.org/10.1016/j.lithos.2020.105702

[38] Feybesse, J.L., Johan, V., Triboulet, C., Guerrot, C., Mayaga-Mikolo, F., Bouchot, V. and N'dong, J.E. (1998) The West Central African Belt: A Model of 2.5 - 2.0 Ga Accretion and Two-Phase Orogenic Evolution. Precambrian Research, 87, 161-216. https://doi.org/10.1016/S0301-9268(97)00053-3

[39] Owona, S., Ondoa, J.M., Ratschbacher, L., Ndzana, S.P.M., Tchoua, F.M. and Ekodeck, G.E. (2011) The Geometry of the Archean, Paleo- and Neoproterozoic Tectonics in the Southwest Cameroon. Comptes Rendus Geoscience, 343, 312-322. https://doi.org/10.1016/j.crte.2010.12.008

[40] Taylor, S.R. and McLennan, S.M. (1985) The Continental Crust: Its Composition and Evolution. Blackwell Publishing, Oxford, UK, 312.

[41] Savko, K.A., Bazikov, N.S. and Artemenko, G.V. (2015) Geochemical Evolution of the Banded Iron Formations of the Voronezh Crystalline Massif in the Early Precambrian: Sources of Matter and Geochronological Constraints. Stratigraphy and Geological Correlation volume, 23, 451-467. https://doi.org/10.1134/S0869593815050068 
[42] Dymek, R.F. and Klein, C. (1988) Chemistry, Petrology and Origin of Banded Iron Formation Lithologies from 3800 MA Isua Supracrustal Belt, West Greenland. Precambrian Research, 39, 247-302. https://doi.org/10.1016/0301-9268(88)90022-8

[43] Mloszewska, A.M., Pecoits, E. and Cates, N.L. (2012) The Composition of Earth's Oldest Iron Formations: The Nuvvuagittuq Supracrustal Belt (Québec, Canada). Earth and Planetary Science Letters, 317-318, 331-342. https://doi.org/10.1016/j.epsl.2011.11.020

[44] Bau, M. and Dulski, P. (1999) Comparing Yttrium and Rare Earths in Hydrothermal Fluids from the Mid-Atlantic Ridge: Implications for Y and REE Behaviour during Near Vent Mixing and for the Y/Ho Ratio of Proterozoic Seawater. Chemical Geology, 155, 77-90. https://doi.org/10.1016/S0009-2541(98)00142-9

[45] Sun, X.-H., Zhu, X.-Q., Tang, H.-S., Zhang, Q. and Luo, T.-Y. (2015) The Gongchangling BIFs from the Anshan-Benxi Area, NE China: Petrological-Geochemical Characteristics and Genesis of High-Grade Iron Ores. Ore Geology Reviews, 60, 112-125. https://doi.org/10.1016/j.oregeorev.2013.12.017

[46] Sun, S.S. and McDonough, W.F. (1989) Chemical and Isotopic Systematics of Oceanic Basalts: Implications for Mantle Composition and Processes. Geological Society, London, Special Publications, 42, 313-345. https://doi.org/10.1144/GSL.SP.1989.042.01.19

[47] McLennan, S.M. (1989) Rare Earth Elements in Sedimentary Rocks: Influence of Provenance and Sedimentary Processes. In: Lipin, B.R. and McKay, G.A., Eds., Geochemistry and Mineralogy of Rare Earth Elements, De Gruyter, Berlin, 169-200. https://doi.org/10.1515/9781501509032-010

[48] Derry, L.A. and Jacobsen, S.B. (1990) The Chemical Evolution of Precambrian Seawater: Evidence from REEs in Banded Iron Formations. Geochimica et Cosmochimica Acta, 54, 2965-2977. https://doi.org/10.1016/0016-7037(90)90114-Z

[49] Kato, Y., Ohta, I., Tsunematsu, T., Watanabe, Y., Isozaki, Y. and Maruyama, S. (1998) Rare Earth Element Variations in Mid-Archean Banded Iron Formations: Implications for the Chemistry of Ocean and Continent and Plate Tectonics. Geochimica et Cosmochimica Acta, 62, 3475-3497. https://doi.org/10.1016/S0016-7037(98)00253-1

[50] Kato, Y., Yamaguchi, K.E. and Ohmoto, H. (2006) Rare Earth Elements in Precambrian Banded Fe Formations: Secular Changes of Ce and Eu Anomalies and Evolution of Atmospheric Oxygen. In: Kessler, S.E. and Ohmoto, H., Eds., Evolution of the Atmosphere, Hydrosphere, and Biosphere on Early Earth: Constraints from Ore Deposits, Geological Society of America, Denver. https://doi.org/10.1130/2006.1198(16)

[51] Bau, M., Schmidt, K., Koschinsky, A., Hein, J., Kuhn, T. and Usui, A. (2014) Discriminating between Different Genetic Types of Marine Ferro-Manganese Crusts and Nodules Based on Rare Earth Elements and Yttrium. Chemical Geology, 381, 1-9. https://doi.org/10.1016/j.chemgeo.2014.05.004

[52] Fryer, B.J. (1983) Rare Earth Elements in Iron-Formation. In: Trendall, A.F. and Morris, R.C., Eds., Developments in Precambrian Geology, Elsevier, Amsterdam, 345-358. https://doi.org/10.1016/S0166-2635(08)70048-3

[53] Barrett, T.J., Fralick, P.W. and Javris, I. (1988) Rare-Earth Element Geochemistry of Some Archean Iron Formations North of Lake Superior, Ontario. Canadian Journal of Earth Sciences, 25, 570-580. https://doi.org/10.1139/e88-055

[54] Bau, M. and Möller, P. (1993) Rare Earth Element Systematics of the Chemically Precipitated Component in Early Precambrian Iron-Formations and the Evolution 
of the Terrestrial Atmosphere-Hydrosphere-Lithosphere System. Geochimica et Cosmochimica Acta, 57, 2239-2249. https://doi.org/10.1016/0016-7037(93)90566-F

[55] Planavsky, N., Bekker, A., Rouxel, O.J., Kamber, B., Hofmann, A., Knudsen, A. and Lyons, T.W. (2010) Rare Earth Element and Yttrium Compositions of Archean and Paleoproterozoic Fe Formations Revisited: New Perspectives on the Significance and Mechanisms of Deposition. Geochimica et Cosmochimica Acta, 74, 6387-6405. https://doi.org/10.1016/j.gca.2010.07.021

[56] Klein, C. (2005) Some Precambrian Banded Iron-Formations (BIFs) from around the World: Their Age, Geologic Setting, Mineralogy, Metamorphism, Geochemistry, and Origins. American Mineralogist, 90, 1473-1499. https://doi.org/10.2138/am.2005.1871

[57] Tchatchueng, R., Dadjo Djamo, H., Ngnotué, T., Tanko Njiosseu, E.L., Traoré, M., Moudioh, C., Wabo, H., Djeutchou, C. and Nzenti, J.P. (2020) Petrography and Major Element Geochemistry of the Endengue Iron Formations, Ntem Complex, South Cameroon. Journal of Geosciences and Geomatics, 8, 15-24.

[58] Bauernhofer, A.H., Hauzenberger, C.A., Wallbrecher, E., Muhongo, S., Hoinkes, G., Mogessie, A., Opiyo-Akech, N. and Tenczer, V. (2009) Geochemistry of Basement Rocks from SE Kenya and NE Tanzania: Indications for Rifting and Early Pan-African Subduction. International Journal of Earth Sciences, 98, 1809-1834. https://doi.org/10.1007/s00531-008-0345-9

[59] Lan, T.G., Fan, H.R., Santosh, M., Hu, F.F., Yang, K.F. and Liu, Y.S. (2014) U-Pb Zircon Chronology, Geochemistry and Isotopes of the Changyi Banded Iron Formation in the Eastern Shandong Province: Constraints on BIF Genesis and Implications for Paleoproterozoic Tectonic Evolution of the North China Craton. Ore Geology Reviews, 56, 472-486. https://doi.org/10.1016/j.oregeorev.2013.06.008

[60] Rudnick, R.L., McLennan, S.M. and Taylor, S.R. (1985) Large Ion Lithophile Elements in Rocks from High-Pressure Granulite Facies Terrains. Geochimica et Cosmochimica Acta, 49, 1645-1655. https://doi.org/10.1016/0016-7037(85)90268-6

[61] Veizer, J., Ala, D., Azmy, K., Bruckschen, P., Buhl, D., Bruhn, F., Carden, G.A.F., Diener, A., Ebneth, S., Godderis, Y., Jasper, T., Korte, C., Pawellek, F. Podlaha, O.G. and Strauss, H. (1999) ${ }^{87} \mathrm{Sr} /{ }^{86} \mathrm{Sr}, \delta^{13} \mathrm{C}$ and $\delta^{18} \mathrm{O}$ Evolution of Phanerozoic Seawater. Chemical Geology, 161, 59-88. https://doi.org/10.1016/S0009-2541(99)00081-9

[62] Tang, H.S., Chen, Y.J., Santosh, M., Zhong, H. and Yang, T. (2013) REE Geochemistry of Carbonates from the Guanmenshan Formation, Liaohe Group, NE Sino-Korean Craton: Implications for Seawater Compositional Change during the Great Oxidation Event. Precambrian Research, 227, 316-336.

https://doi.org/10.1016/j.precamres.2012.02.005

[63] Rao, T.G. and Naqvi, S.M. (1995) Geochemistry, Depositional Environment and Tectonic Setting of the BIF's of the Late Archean Chitradurga Schist Belt, India. Chemical Geology, 121, 217-243. https://doi.org/10.1016/0009-2541(94)00116-P

[64] Pecoits, E., Gingras, M.K., Barley, M.E., Kappler A., Posth, N.R. and Konhauser, K.O. (2009) Petrography and Geochemistry of the Dales Gorge Banded Iron Formation: Paragenetic Sequence, Source and Implications for Palaeo-Ocean Chemistry. Precambrian Research, 172, 163-187.

https://doi.org/10.1016/j.precamres.2009.03.014

[65] Condie, K.C. (1993) Chemical Composition and Evolution of the Upper Continental Crust: Contrasting Results from Surface Samples and Shales. Chemical Geology, 104, 1-37. https://doi.org/10.1016/0009-2541(93)90140-E

[66] Thurston, P.C., Kamber, B.S. and Whitehouse, M. (2012) Archaean Cherts in 
Banded Iron Formation: Insight into Neoarchaean Ocean Chemistry and Depositional Processes. Precambrian Research, 214-215, 227-257. https://doi.org/10.1016/j.precamres.2012.04.004

[67] Toth, J.R. (1980) Deposition of Submarine Crusts Rich in Manganese and Iron. GSA Bulletin, 91, 44-54. https://doi.org/10.1130/0016-7606(1980)91<44:DOSCRI >2.0.CO;2

[68] Hein, J.R., Conrad, T., Mizell, K., Banakar, K.V., Frey, F.A. and Sager, W.W. (2016) Controls on Ferromanganese Crust Composition and Reconnaissance Resource Potential, Ninety East Ridge, Indian Ocean. Elsevier Deep Sea Research Part I: Oceanographic Research Papers, 110, 1-19. https://doi.org/10.1016/j.dsr.2015.11.006

[69] Bingen, B., Demaiffe, D. and Hergoten, J. (1996) Redistribution of REE, Thorium and Uranium over Accessory Minerals in the Course of Amphibolite to Granulite Facies Metamorphism: The Role of Apatite and Monazite in Orthogneisses from South-Eastern Norway. Geochimica et Cosmochimica Acta, 60, 1341-1354. https://doi.org/10.1016/0016-7037(96)00006-3

[70] Afifya, A.M., Sanz-Monteroa, M.E. and Calvo, J.P. (2018) Differentiation of Ironstone Types by Using Rare Earth Elements and Yttrium Geochemistry-A Case Study from the Bahariya Region, Egypt. Ore Geology Reviews, 96, 247-261. https://doi.org/10.1016/j.oregeorev.2018.04.019

[71] Klinkhammer, G., Elderfield, H. and Hudson, A. (1983) Rare Earth Elements in Seawater near Hydrothermal Vents. Nature, 305, 185-188. https://doi.org/10.1038/305185a0

[72] Kamber, B.S. (2010) Archean Mafic-Ultramafic Volcanic Landmasses and Their Effect on Ocean-Atmosphere Chemistry. Chemical Geology, 274, 19-28. https://doi.org/10.1016/j.chemgeo.2010.03.009

[73] Zhang, J. and Nozaki, Y. (1996) Rare Earth Elements and Yttrium in Seawater: ICP-MS Determinations in the East Caroline, Coral Sea, and South Fiji Basins of the Western South Pacific Ocean. Geochimica et Cosmochimica Acta, 60, 4631-4644. https://doi.org/10.1016/S0016-7037(96)00276-1

[74] Michard, A., Michard, G., Stuben, D., Stoffers, P., Cheminée, J.-L. and Binard, N. (1993) Submarine Thermal Springs Associated with Young Volcanoes: The Teahitia Vents, Society Islands Pacific Ocean. Geochimica et Cosmochimica Acta, 57, 4977-4986. https://doi.org/10.1016/S0016-7037(05)80003-1

[75] Cabral, A.R., Lehmann B., Seabra Gomes, A.A. and Pasava, J. (2016) Episodic Negative Anomalies of Cerium at the Depositional Onset of the 2.65-Ga Itabira Iron Formation, Quadrilátero Ferrífero of Minas Gerais, Brazil. Precambrian Research, 276, 101-109. https://doi.org/10.1016/j.precamres.2016.01.031

[76] Ganno, S., Njiosseu, T.E.L., Kouankap, N.G.D., Djoukouo, S.A.P., Moudioh, C., Ngnotué, T. and Nzenti, J.P. (2017) A Mixed Seawater and Hydrothermal Origin of Superior-Type Banded Iron Formation (BIF)-Hosted Kouambo Iron Deposit, Palaeoproterozoic Nyong Series, Southwestern Cameroon: Constraints from Petrography and Geochemistry. Ore Geology Reviews, 80, 860-875.

https://doi.org/10.1016/j.oregeorev.2016.08.021

[77] Graf, J.L., O’Connor, E.A. and Van Leeuwen, P. (1994) Rare Earth Element Evidence of Origin and Depositional Environment of Late Proterozoic Ironstone Beds and Manganese-Oxide Deposits, SW Brazil and SE Bolivia. Journal of South America Earth Sciences, 7, 115-133. https://doi.org/10.1016/0895-9811(94)90003-5

[78] Chombong, N.N., Suh, C.E., Lehmann, B., Vishiti, A., Ilouga, D.C., Shemang, E.M., 
Tantoh, B.S. and Kedia, A.C. (2017) Host Rock Geochemistry, Texture and Chemical Composition of Magnetite in Iron Ore in the Neoarchaean Nyong Unit in Southern Cameroon. Applied Earth Science, 126, 129-145. https://doi.org/10.1080/03717453.2017.1345507

[79] Lascelles, D.F. (2007) Black Smokers and Density Currents: A Uniformitarian Model for the Genesis of Banded Iron-Formations. Ore Geology Reviews, 32, 381-411. https://doi.org/10.1016/j.oregeorev.2006.11.005

[80] German, C.R. and Elderfield, H. (1990) Application of the Ce Anomaly as a Paleo Redox Indicator: The Ground Rules. Paleoceanography and Paleoceanography, 5, 823-833. https://doi.org/10.1029/PA005i005p00823

[81] Bekker, A., Slack, J.F., Planavsky, N., Krapez, B., Hofmann, A., Konhauser, K.O. and Rouxel, O.J. (2010) Iron Formation: The Sedimentary Product of a Complex Interplay among Mantle, Tectonic, Oceanic and Biospheric Processes. Economic Geolo$g y$, 105, 467-508. https://doi.org/10.2113/gsecongeo.105.3.467

[82] Byrne, R. and Sholkovitz, E. (1996) Marine Chemistry and Geochemistry of the Lanthanides. In: Gschneider Jr., K.A. and Eyring, L., Eds., Handbook on the Physics and Chemistry of the Rare Earths, Vol. 23, Elsevier, Amsterdam, 497-593. https://doi.org/10.1016/S0168-1273(96)23009-0

[83] Kakuwa, Y. and Matsumoto, R. (2006) Cerium Negative Anomaly Just before the Permian and Triassic Boundary Event-The Upward Expansion of Anoxia in the Water Column. Palaeogeography, Palaeoclimatology, Palaeoecology, 229, 335-344. https://doi.org/10.1016/j.palaeo.2005.07.005

[84] Maynard, J.B. (2010) The Chemistry of Manganese Ores through Time: A Signal of Increasing Diversity of Earth-Surface Environments. Economic Geology, 105, 535-552. https://doi.org/10.2113/gsecongeo.105.3.535

[85] Braun, J.J., Pagel, M., Muller, J.-P., Bilong, P., Michard, A. and Guillet, B. (1990) Cerium Anomalies in Lateritic Profiles. Geochimica et Cosmochimica Acta, 54, 781-795. https://doi.org/10.1016/0016-7037(90)90373-S

[86] Boulangé, B. and Colin, F. (1994) Rare Element Mobility during Conversion of Nepheline Syenite into Lateritic Bauxite at Passo-Quatro, Minas Gerais, Brazil. Applied Geochemistry, 9, 701-711. https://doi.org/10.1016/0883-2927(94)90029-9

[87] Koeppenkastrop, D. and De Carlo, E.H. (1992) Sorption of Rare-Earth Elements from Seawater onto Synthetic Mineral Particles-An Experimental Approach. Chemical Geology, 95, 251-263. https://doi.org/10.1016/0009-2541(92)90015-W

[88] Soh, T.L., Tankwa, M.N., Chongtao, W., Ganno, S., Ngnotue, T., Kouankap, N.G.D., Shaamu, J.S., Zhang, J. and Nzenti, J.P. (2018) Geology and Geochemical Constrains on the Origin and Depositional Setting of the Kpwa-Atog Boga Banded Iron Formations (BIFs), Northwestern Congo Craton, Southern Cameroon. Ore Geology Reviews, 95, 620-638. https://doi.org/10.1016/j.oregeorev.2018.03.017

[89] Fryer, B. (1977) Rare Earth Evidence in Iron-Formations for Changing Precambrian Oxidation States. Geochimica et Cosmochimica Acta, 41, 361-367. https://doi.org/10.1016/0016-7037(77)90263-0

[90] Amstrong-Altrin, J.S., Lee, Y.I., Verma, S.P. and Ramasamy, S. (2004) Geochemistry of Sandstones from the Upper Miocene Kudankulam Formation, Southern India: Implications for Provenance, Weathering, and Tectonic Setting. Journal of Sedimentation Research, 74, 285-297. https://doi.org/10.1306/082803740285

[91] Jacobsen, S.B. and Pimentel-Klose, M.R. (1988) Nd Isotopic Variations in Precambrian Banded Iron Formations. Geophysical Research Letters, 15, 393-396.

https://doi.org/10.1029/GL015i004p00393 
[92] Klein, C. and Beukes, N.J. (1989) Geochemistry and Sedimentology of a Facies Transition from Limestone to Iron-Formation Deposition in the Early Proterozoic Transvaal Super-Group, South Africa. Economic Geology, 84, 1733-1774. https://doi.org/10.2113/gsecongeo.84.7.1733

[93] Beukes, N.J. and Klein, C. (1990) Geochemistry and Sedimentology of a Facies Transition-From Microbanded to Granular Iron-Formation-In the Early Proterozoic Transvaal Supergroup, South Africa. Precambrian Research, 47, 99-139. https://doi.org/10.1016/0301-9268(90)90033-M 